

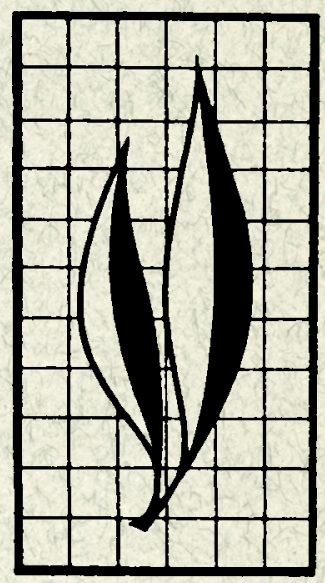

In the work reported here, gas chromatography was used to study production of volatiles related to variety, fruit maturity, ripening, and storage of apples.

Varieties differed in the kind and amount of volatiles produced, although closely related varieties sometimes produced similar patterns of volatiles. Mature apples produced appreciable amounts of volatiles sooner after harvest and attained maximum rates of production more quickly than did immature apples. Maximum rates of production of volatiles attained by apples following storage at $32^{\circ} \mathrm{F}$ for 2 to 6 months were usually lower than those from freshly harvested apples.

Comparison of relative retention times of known alcohols and esters with those for the apple volatiles, as determined on two different chromatographic columns, provided some evidence for identification of the apple volatiles.

\section{THE AUTHORS:}

D. S. Brown is Professor of Pomology and Pomologist in the Experiment Station, Davis; J. R. Buchanan is Associate Specialist in Pomology, Davis; J. R. Hicks, formerly Laboratory Technician II, Department of Pomology, Davis, is now Research Assistant, Department of Horticulture, University of Maryland. 


\title{
Volatiles from Apples as Related to Variety, Season, Maturity, and Storage ${ }^{1}$
}

\section{INTRODUCTION}

\begin{abstract}
ANDERson (1965), ${ }^{2}$ Ulrich (1958), Hulme (1958), and Pentzer and Heinze (1954) reviewed various aspects of research on apple volatiles, including evidence as to their nature, identification, and relation to apple metabolism. Earlier studies were, as mentioned by Smock and Neubert (1950), usually concerned with total volatiles, presumably due largely to difficulties in analytically separating various components. Today, gas chromatography has given impetus to detailed investigations of fruit volatiles even though it has certain limitations (Flath, 1967). It was used by Ahmed and Scott (1963) in identifying strawberry volatiles and evaluating factors influencing their production, by Lim and Romani (1964) with peaches, and by Stackenbrok (1961), Somogyi et al. (1964), MacGregor et al. (1964), Grevers and Does-

burg (1965), and Flath et al. (1967) with apples.

In 1964 the authors began a study of apple volatiles in relation to variety, maturity and ripeness, and storage (Brown et al., 1966), and this was continued in 1965 for comparisons over two seasons particularly with Royal Red Delicious and Starkrimson varieties. The 1965 study provided information on the effect of a 3-month period of cold storage on volatile production, as well as one of 5 to 6 months duration. Observations were also made on Ruby and Melrose for comparison with the two Delicious sports. A modification of the method of taking the gas samples, and use of a more sensitive chromatographic column than was used in 1964, permitted an improvement in separating volatile components and in expressing their production patterns.
\end{abstract}

\section{METHODS}

Sampling procedures. Royal Red Delicious and Starkrimson apples were picked near Watsonville on September 8, 22 and 28, and October 5 in 1964, and on September 8 and 21, and Octo- ber 5 and 14 in 1965 . The first picking date was chosen because of its proximity to the time Delicious apples were officially released for commercial harvest in the Watsonville area. Sample

\footnotetext{
${ }^{1}$ Submitted for publication June 7, 1967.

${ }^{2}$ See "Literature Cited" for publications referred to in text by author and date.
} 
trees (one of Starkrimson and two of Royal Red) were part of a variety plot; on each date approximately 100 apples of each variety were picked in about equal numbers from upper and lower portions of the trees. Fruit was selected at random; small or poorly colored apples were not picked. Picked apples were taken to Davis, the same day and stored at $32^{\circ} \mathrm{F}$. After 3 or 4 days they were moved to $68^{\circ} \mathrm{F}$ and representative samples were selected for determinations of $\mathrm{CO}_{2}, \mathrm{C}_{2} \mathrm{H}_{4}$, and other volatiles, and for measurement of firmness and soluble solids. The initial brief period in cold storage prior to testing was adopted as standard procedure because production patterns for $\mathrm{CO}_{2}$ and volatiles, especially at the start of a run, tended to be more uniform with it than without it. For convenience, these samples will be referred to as "freshly harvested" and the determinations on them as having been made shortly after harvest, in order to distinguish them from other samples from the 1965 harvest stored at $32^{\circ} \mathrm{F}$ until November 28, 1965, or until February 7, 1966, before determinations were made.

Samples of Melrose and Ruby apples were collected in 1965 on September 21 and October 5, 14 and 28, and on October 14 and 28, and November 4, respectively, from one tree of each variety in the same orchard near Watsonville. They were handled and tested in the same way as the Delicious samples.

Duplicate 5- to 6-apple samples weighing approximately $1 \mathrm{~kg}$ were placed in 1-gallon jars at $68^{\circ} \mathrm{F} . \mathrm{CO}_{2}$ was determined by the method of Claypool and Keefer (1942), and $\mathrm{C}_{2} \mathrm{H}_{4}$ as described by Maxie et al. (1965). In 1965 other volatiles were determined on a $10 \mathrm{ml}$ gas sample removed with a gastight syringe from effluent air moving through the jars at the same flow rate used in the $\mathrm{CO}_{2}$ and $\mathrm{C}_{2} \mathrm{H}_{4}$ measurements (approximately $200 \mathrm{ml} / \mathrm{min}$. for Starkrimson, Royal Red Delicious and Ruby; and $125 \mathrm{ml} / \mathrm{min}$. for Melrose). In 1964 the sample was removed from the head space over the fruit after stopping air flow through the jars (Brown et al., 1966). Volatiles were determined at intervals of 2 to 7 days for a period of 30 to 40 days-or until fruits were overripe.

Chromatographic procedures. The chromatographic instrument in 1965 was an Aerograph $\mathrm{Hy}-\mathrm{Fi}$ Model A-600B and auxiliary oven Model 550, both equipped with flame ionization detectors and isothermal temperature controllers, Model 328. One oven had a 10foot $\times 1 / 8$-inch column, similar to that used in 1964 (Brown et al., 1966), packed with 60 - to 80 -mesh acid-washed chromosorb-P coated with diethylene glycol succinate (DEGS), 20 per cent by weight; the injector chamber was heated to $150^{\circ} \mathrm{C}$. The sample was eluted through the column by nitrogen at a flow rate of approximately $35 \mathrm{ml}$ per minute at an oven temperature of $79^{\circ} \mathrm{C}$. The flame ionizer was supplied with hydrogen and air at approximately 30 and $300 \mathrm{ml}$ per minute, respectively. In the other oven was a 5 -foot $x 1 / 8$-inch column packed with 100 - to 120 -mesh acid-washed chromosorb-P treated with dimethyl dichlorosilane and coated, 20 per cent by weight, with a material called FFAP by the manufacturer (Aerograph). The exact structure of the coating material, an esterification product of a polyethylene glycol and 2-nitro terepthalic acid, is not known. The sample was eluted through the column by nitrogen at a flow rate of approximately $25 \mathrm{ml}$ per minute at an oven temperature of $69^{\circ} \mathrm{C}$. The flame ionizer was supplied with hydrogen and oxygen at approximately 30 and 200 $\mathrm{ml}$ per minute, respectively. The recorder was a Brown-Honeywell Model 153 having a range of 1 millivolt full scale.

The column coated with FFAP was used exclusively in 1965 in the variety, 
maturity, and ripening comparisons because its greater sensitivity made it more suitable for samples taken from effluent air moving through sample jars.

Data from the chromatograms were expressed quantitatively by multiplying retention time in minutes by peak height in millivolts. The unit "millivoltminutes (mv-min.)" was used for presenting data from the 1964 samples in which air flow through sample jars was stopped for 50 minutes before taking gas samples (Brown et al., 1966). When gas samples of effluent air from sample jars were taken in 1965, the expression was modified to "volt-minutes per kilogram of fruit per hour (v-min./kg/ hr.)" by using appropriate conversion factors based on flow rates through jars. Commonly, there was good agreement in data from the duplicate samples, so averages of quantitative data were

TABLE 1

PRODUCTION OF VOLATILES AT PEAKS 3, 6, 7, AND 11 AS DETERMINED ON THE DEGS COLUMN FOR TWO SAMPLES $(1,2)$ OF ROYAL RED DELICIOUS HARVESTED ON FOUR DATES IN 1964, EXPRESSED AS MILLIVOLT-MINUTES

\begin{tabular}{|c|c|c|c|c|c|c|c|c|c|c|c|c|}
\hline \multirow{2}{*}{ Days* } & \multicolumn{3}{|c|}{ Peak 3} & \multicolumn{3}{|c|}{ Peak 6} & \multicolumn{3}{|c|}{ Peak 7} & \multicolumn{3}{|c|}{ Peak 11} \\
\hline & 1 & 2 & $\begin{array}{l}\text { Aver- } \\
\text { age }\end{array}$ & 1 & 2 & $\begin{array}{l}\text { Aver- } \\
\text { age }\end{array}$ & 1 & 2 & $\begin{array}{c}\text { Aver- } \\
\text { age }\end{array}$ & 1 & 2 & $\begin{array}{c}\text { Aver- } \\
\text { age }\end{array}$ \\
\hline \multicolumn{13}{|l|}{ Harvested 9/8: } \\
\hline $6 \ldots \ldots \ldots \ldots \ldots \ldots \ldots \ldots \ldots \ldots \ldots$ & 0 & 0 & 0.0 & 0 & 0 & 0.0 & 0 & 0 & 0.0 & 0 & $\mathbf{0}$ & 0.0 \\
\hline $11 \ldots \ldots \ldots \ldots \ldots \ldots \ldots \ldots \ldots \ldots \ldots \ldots$ & 0 & 1 & 0.5 & 0 & 5 & 2.5 & 0 & 13 & 6.5 & 0 & 1 & 0.5 \\
\hline $15 \ldots \ldots \ldots \ldots \ldots \ldots \ldots \ldots \ldots$ & 0 & 8 & 4.0 & 0 & 22 & 11.0 & 1 & 66 & 33.5 & 0 & 8 & 4.0 \\
\hline $20 \ldots \ldots \ldots \ldots \ldots \ldots \ldots \ldots \ldots \ldots$ & 0 & 29 & 14.5 & 0 & 38 & 19.0 & 3 & 90 & 46.5 & 1 & 13 & 7.0 \\
\hline $26 \ldots \ldots \ldots \ldots \ldots \ldots \ldots \ldots \ldots \ldots$ & 6 & 52 & 29.0 & 18 & 43 & 30.5 & 57 & 80 & 68.5 & 7 & 14 & 10.5 \\
\hline $32 \ldots \ldots \ldots \ldots \ldots \ldots \ldots \ldots \ldots \ldots$ & 29 & 64 & 46.5 & 37 & 37 & 37.0 & 92 & 61 & 76.5 & 10 & 12 & 11.0 \\
\hline $38 \ldots \ldots \ldots \ldots \ldots \ldots \ldots \ldots \ldots \ldots$ & 42 & 59 & 50.5 & 30 & 30 & 30.0 & 64 & 44 & 54.0 & 11 & 11 & 11.0 \\
\hline $43 \ldots \ldots \ldots \ldots \ldots \ldots \ldots \ldots \ldots \ldots \ldots \ldots \ldots \ldots \ldots$ & 76 & 82 & 79.0 & 42 & 35 & 38.5 & 74 & 42 & 58.0 & 18 & 9 & 9.0 \\
\hline \multicolumn{13}{|l|}{ Harvested 9/22: } \\
\hline $4 \ldots \ldots \ldots \ldots$ & 0 & 0 & 0.0 & 0 & 0 & 0.0 & 2 & 2 & 2.0 & $\mathbf{0}$ & 0 & 0.0 \\
\hline $8 \ldots \ldots \ldots \ldots \ldots \ldots \ldots \ldots \ldots \ldots \ldots$ & 1 & 2 & 1.5 & 7 & 9 & 8.0 & 22 & 27 & 24.5 & 2 & 2 & 2.0 \\
\hline $14 \ldots \ldots \ldots \ldots \ldots \ldots \ldots \ldots \ldots$ & 15 & 19 & 17.0 & 35 & 38 & 36.5 & 60 & 70 & 65.0 & 12 & 11 & 11.5 \\
\hline $20 \ldots \ldots \ldots \ldots \ldots \ldots \ldots \ldots \ldots \ldots$ & 38 & 44 & 41.0 & 42 & 49 & 45.5 & 67 & 79 & 73.0 & 17 & 18 & 17.5 \\
\hline $25 \ldots \ldots \ldots \ldots \ldots \ldots \ldots \ldots \ldots \ldots$ & 43 & 48 & 45.5 & 38 & 37 & 37.5 & 59 & 57 & 58.0 & 17 & 17 & 17.0 \\
\hline $31 \ldots \ldots \ldots \ldots \ldots \ldots \ldots \ldots \ldots$ & 46 & 51 & 48.5 & 30 & 29 & 29.5 & 45 & 39 & 42.0 & 15 & 14 & 14.5 \\
\hline $35 \ldots \ldots \ldots \ldots \ldots \ldots \ldots \ldots \ldots \ldots \ldots$ & 41 & 42 & 41.5 & 26 & 26 & 26.0 & 34 & 31 & 32.5 & 8 & 9 & 8.5 \\
\hline $41 \ldots \ldots \ldots \ldots \ldots \ldots \ldots \ldots \ldots \ldots \ldots$ & 42 & 37 & 39.5 & 24 & 23 & 23.5 & 27 & 21 & 24.0 & 8 & 8 & 8.0 \\
\hline \multicolumn{13}{|l|}{ Harvested 9/28: } \\
\hline $4 \ldots \ldots \ldots \ldots \ldots \ldots \ldots \ldots \ldots \ldots \ldots$ & 0 & 0 & 0.0 & 0 & 2 & 1.0 & 4 & 8 & 6.0 & 0 & $\mathbf{0}$ & 0.0 \\
\hline $9 \ldots \ldots \ldots \ldots \ldots \ldots \ldots \ldots \ldots$ & 4 & $\mathbf{5}$ & 4.5 & 16 & 22 & 19.0 & 41 & 50 & 45.5 & 5 & 8 & 6.5 \\
\hline $14 \ldots \ldots \ldots \ldots \ldots \ldots \ldots \ldots \ldots \ldots \ldots$ & 23 & 21 & 22.0 & 49 & 52 & 50.5 & 74 & 78 & 76.0 & 17 & 19 & 18.0 \\
\hline $20 \ldots \ldots \ldots$ & 35 & 44 & 39.5 & 49 & 57 & 53.0 & 67 & 76 & 71.5 & 20 & 22 & 21.0 \\
\hline $26 \ldots \ldots \ldots \ldots \ldots \ldots \ldots \ldots \ldots$ & 50 & 55 & 52.5 & 45 & 50 & 47.5 & 60 & 65 & 62.5 & 19 & 22 & 20.5 \\
\hline $30 \ldots \ldots \ldots \ldots \ldots \ldots \ldots \ldots \ldots \ldots$ & 39 & 52 & 45.5 & 34 & 42 & 38.0 & 43 & 50 & 46.5 & 13 & 15 & 14.0 \\
\hline $35 \ldots \ldots \ldots \ldots \ldots \ldots \ldots \ldots \ldots \ldots$ & 40 & 47 & 43.5 & 31 & 36 & 33.5 & 36 & 42 & 39.0 & 12 & 13 & 12.5 \\
\hline $40 \ldots \ldots \ldots \ldots \ldots \ldots \ldots \ldots \ldots \ldots$ & 39 & 49 & 44.0 & 31 & 33 & 32.0 & 31 & 31 & 31.0 & 10 & 11 & 10.5 \\
\hline \multicolumn{13}{|l|}{ Harvested 10/5: } \\
\hline $4 \ldots \ldots \ldots \ldots$ & 0 & 2 & 1.0 & 1 & 7 & 4.0 & 9 & 26 & 17.5 & $\mathbf{0}$ & 2 & 1.0 \\
\hline $8 \ldots \ldots \ldots \ldots \ldots \ldots \ldots \ldots \ldots \ldots \ldots$ & 3 & 8 & 5.5 & 16 & 24 & 20.0 & 34 & 48 & 41.0 & 5 & 9 & 7.0 \\
\hline $14 \ldots \ldots \ldots \ldots \ldots \ldots \ldots \ldots \ldots \ldots \ldots$ & 20 & 23 & 21.5 & 46 & 41 & 43.5 & 58 & 58 & 58.0 & 17 & 17 & 17.0 \\
\hline $20 \ldots \ldots \ldots \ldots \ldots \ldots \ldots \ldots \ldots$ & 37 & 36 & 36.5 & 39 & 39 & 39.0 & 57 & 61 & 59.0 & 17 & 16 & 16.5 \\
\hline $25 \ldots \ldots \ldots \ldots \ldots \ldots \ldots \ldots \ldots$ & 37 & 38 & 37.5 & 36 & 36 & 36.0 & 45 & 50 & 47.5 & 14 & . & $\ldots$ \\
\hline $29 \ldots \ldots \ldots$ & 39 & 41 & 40.0 & 34 & 34 & 34.0 & 41 & 46 & 43.5 & 14 & 13 & 13.5 \\
\hline $34 \ldots \ldots \ldots \ldots \ldots \ldots \ldots \ldots \ldots$ & 37 & 34 & 35.5 & 30 & 30 & 30.0 & 34 & 39 & 36.5 & 11 & 12 & 11.5 \\
\hline $40 \ldots \ldots \ldots \ldots \ldots \ldots \ldots \ldots \ldots$ & 32 & 29 & 30.5 & 26 & 24 & 25.0 & 26 & 29 & 27.5 & 8 & 8 & 8.0 \\
\hline
\end{tabular}

* Days at $68^{\circ} \mathrm{F}$ following 3 days at $32^{\circ} \mathrm{F}$ after harvest. 


\begin{tabular}{|c|c|c|c|c|c|c|}
\hline \multirow{16}{*}{ 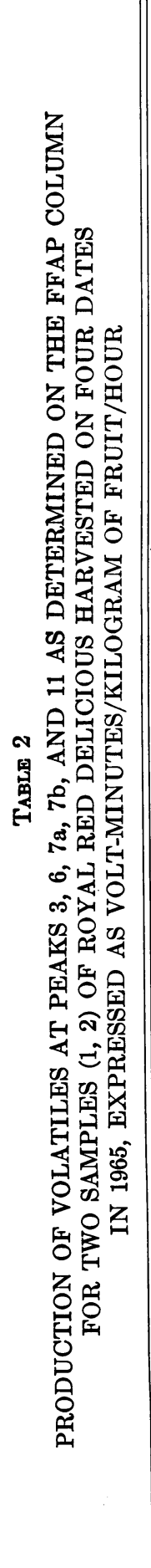 } & \multirow{3}{*}{ 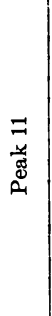 } & 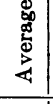 & 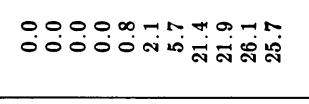 & 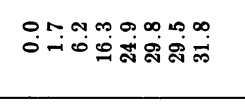 & 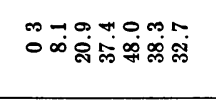 & 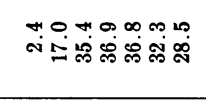 \\
\hline & & ه & 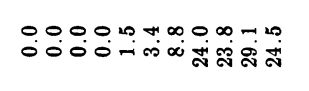 & 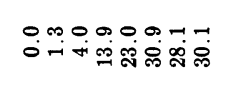 & 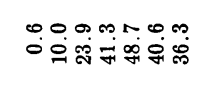 & 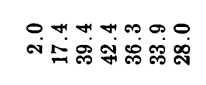 \\
\hline & & - & 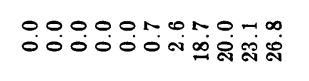 & 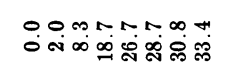 & 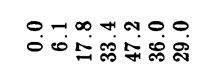 & 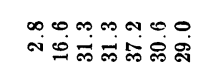 \\
\hline & \multirow{3}{*}{$\begin{array}{l}\text { R } \\
\text { 总 } \\
\text { ond }\end{array}$} & 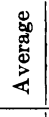 & 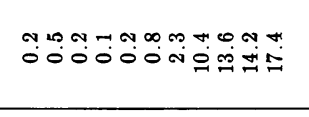 & 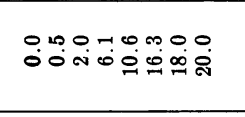 & 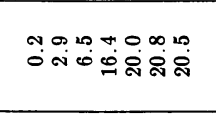 & 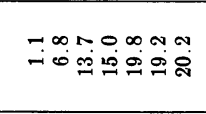 \\
\hline & & $\sim$ & 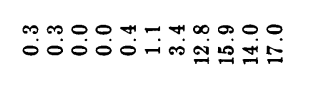 & 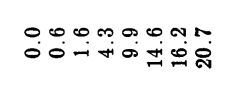 & 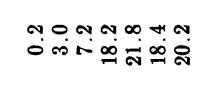 & 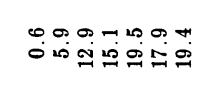 \\
\hline & & - & 00000000 & 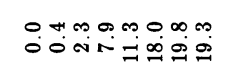 & 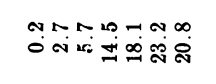 & 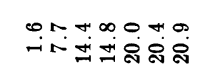 \\
\hline & \multirow{3}{*}{ 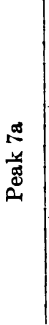 } & 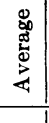 & 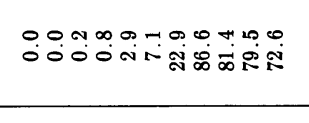 & 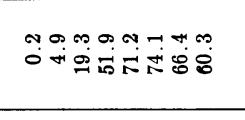 & ஸุ & 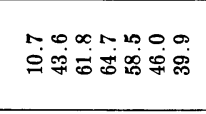 \\
\hline & & $\sim$ & 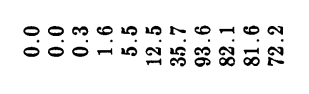 & 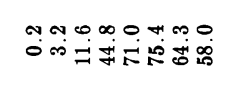 & 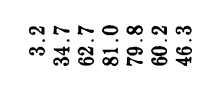 & 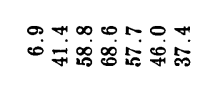 \\
\hline & & -4 & 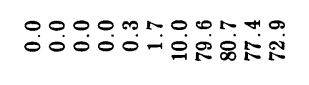 & 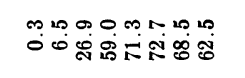 & 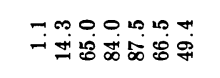 & 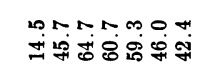 \\
\hline & \multirow{3}{*}{ 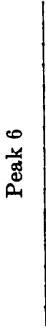 } & 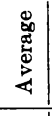 & 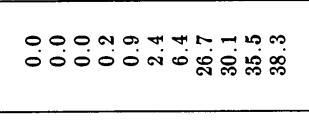 & 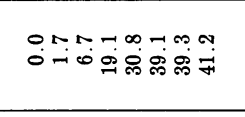 & 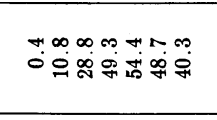 & 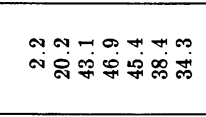 \\
\hline & & $\sim$ & 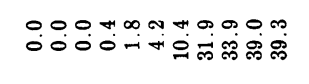 & 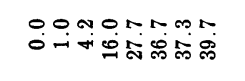 & 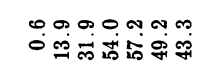 & 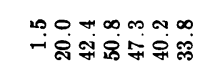 \\
\hline & & - & 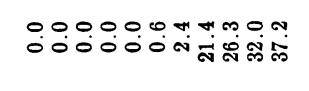 & 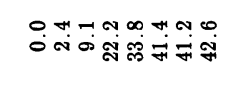 & 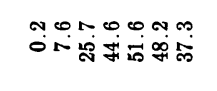 & 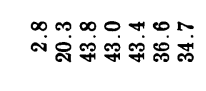 \\
\hline & \multirow{3}{*}{ 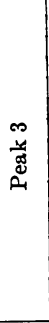 } & 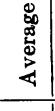 & 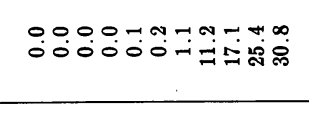 & 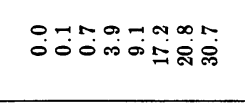 & 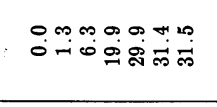 & 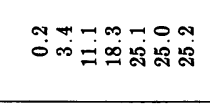 \\
\hline & & N & 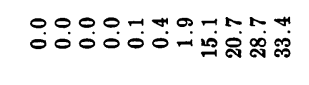 & 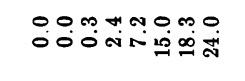 & 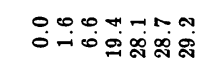 & $\begin{array}{ll}0 \\
0\end{array}$ \\
\hline & & - & 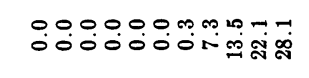 & 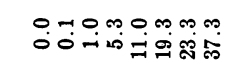 & 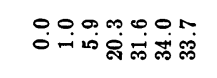 & 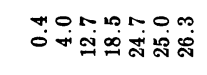 \\
\hline & & & 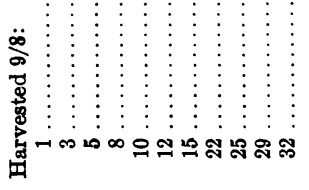 & 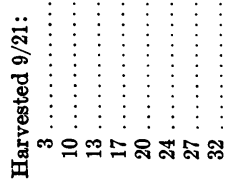 & 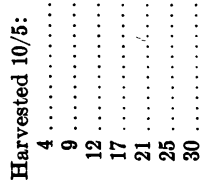 & 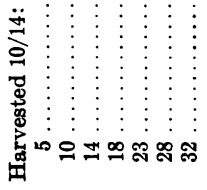 \\
\hline
\end{tabular}


plotted against time and smooth curves were drawn by inspection to depict production patterns in the test runs. To show variability in duplicate samples, however, data for Royal Red Delicious from both seasons were tabulated (tables 1 and 2). The averages in these tables were used in plotting Royal Red curves in figures 1,2,3 and 4. Curves for data from the stored samples of Melrose and Ruby were not prepared, so data from those samples are presented in tabular form (tables $3,4,5$, and 6$)$.

Samples of known alcohols and esters were run on both columns. Relative retention times, using the retention time of butyl acetate as a reference, were calculated for known compounds and for peaks from the apple volatiles.

Maturity tests. Flesh firmness and soluble solids were measured on 10 apples visually judged as being comparable to those used for determining the volatiles. Firmness was measured with a Magness-Taylor pressure tester fitted with a $7 / 16$-inch plunger, making two readings per fruit. Soluble solids were determined with a hand refractometer on juice extracted in a juicer from longitudinal segments, two per apple, cut from opposite sides of each of the 10 fruits used for the pressure test.

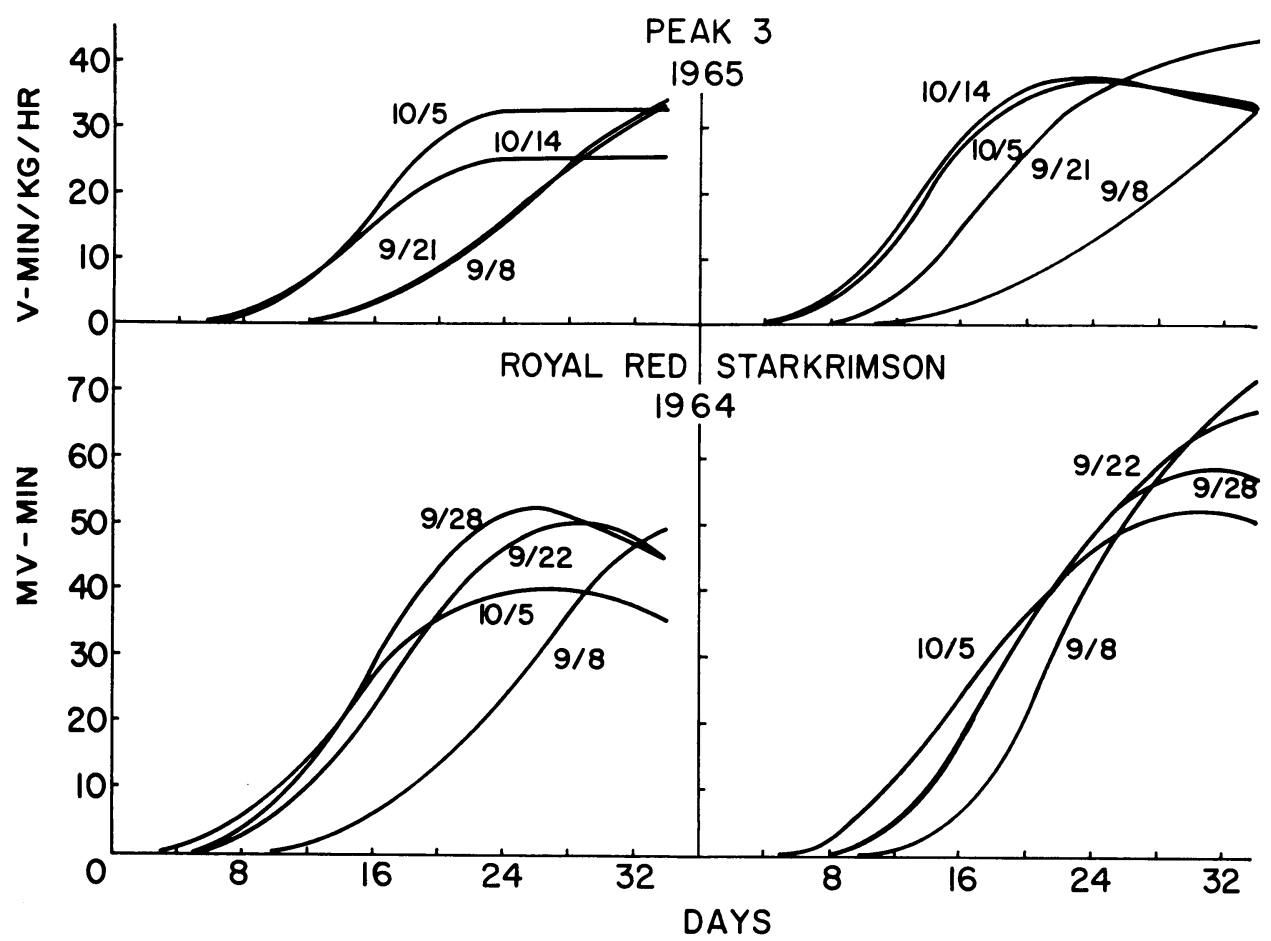

Fig. 1. Production curves for volatile at Peak 3 as determined on DEGS column in 1964 and FFAP column in 1965 for Royal Red Delicious and Starkrimson shortly after harvest dates indicated. Mv-min. = retention time in minutes multiplied by peak height in millivolts.. V-min./ $\mathrm{kg} / \mathrm{hr} .=$ volt minutes per kilogram of fruit per hour. 


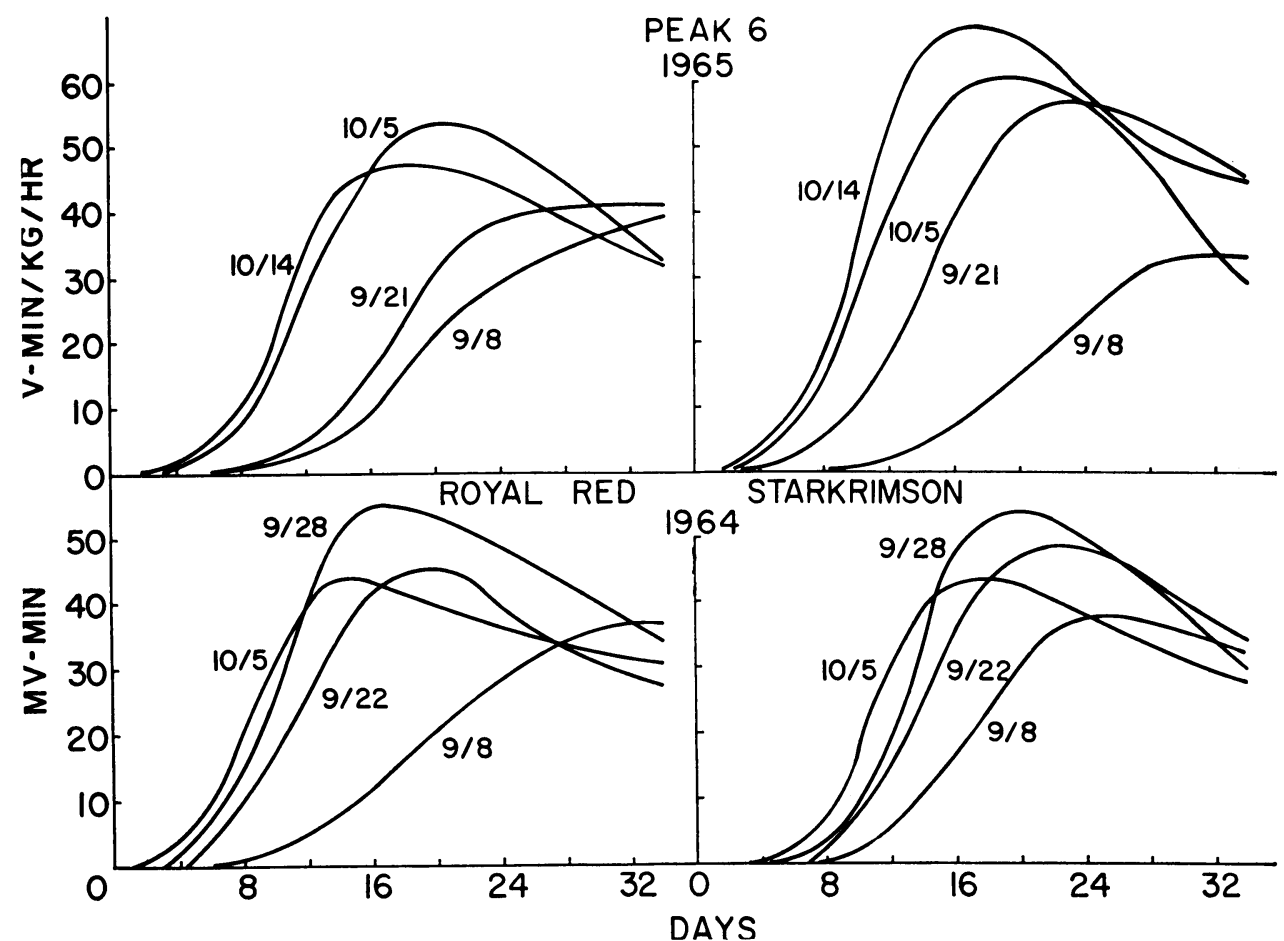

Fig. 2. Production curves for the volatile at Peak 6 as determined on the DEGS column in 1964 and the FFAP column in 1965 for Royal Red Delicious and Starkrimson shortly after the harvest dates indicated. 


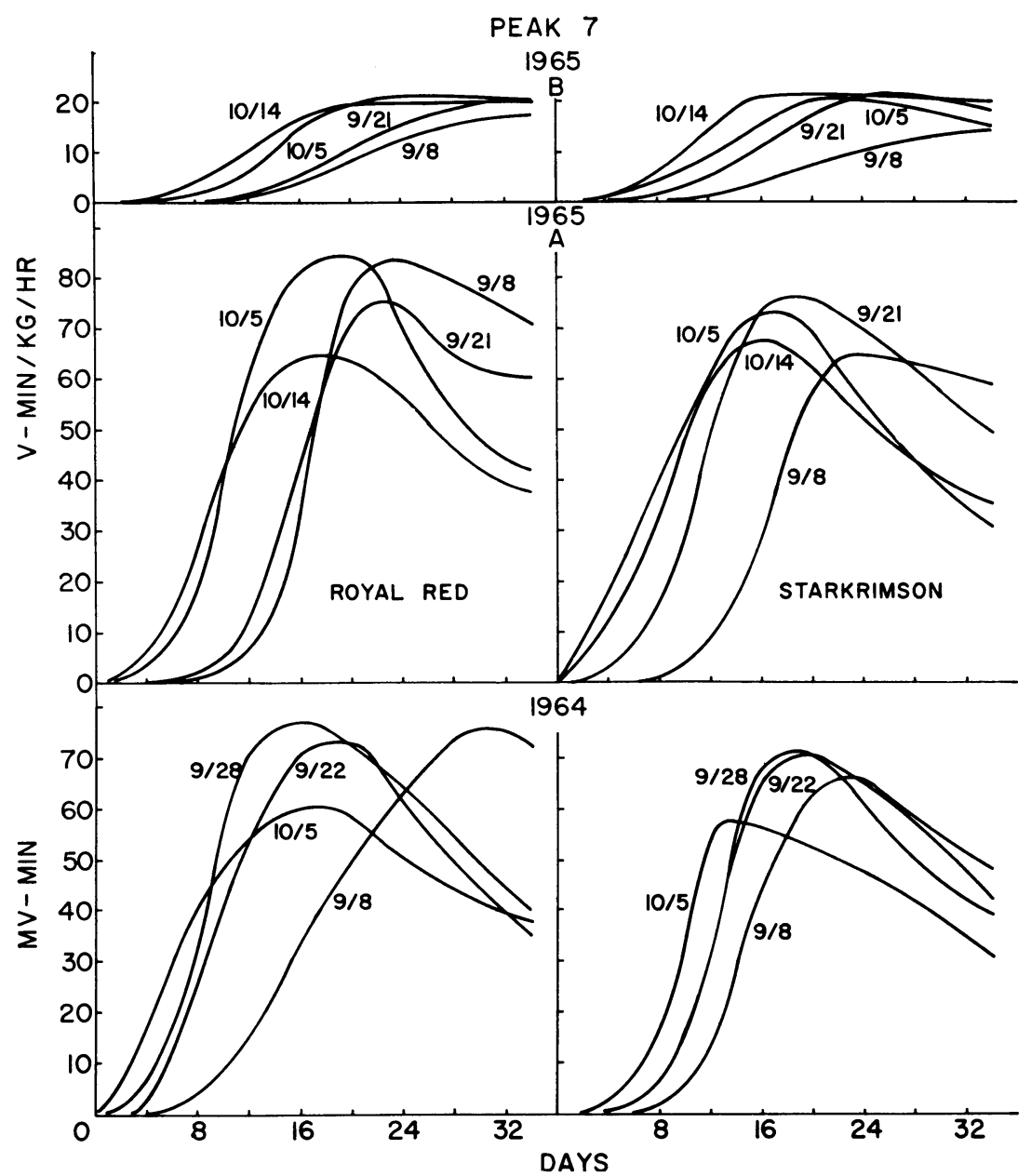

Fig. 3. Production curves as determined for the volatiles at Peak 7 on the DEGS column in 1964 and at Peaks 7A and 7B on the FFAP column in 1965 for Royal Red Delicious and Starkrimson shortly after harvest dates indicated. 


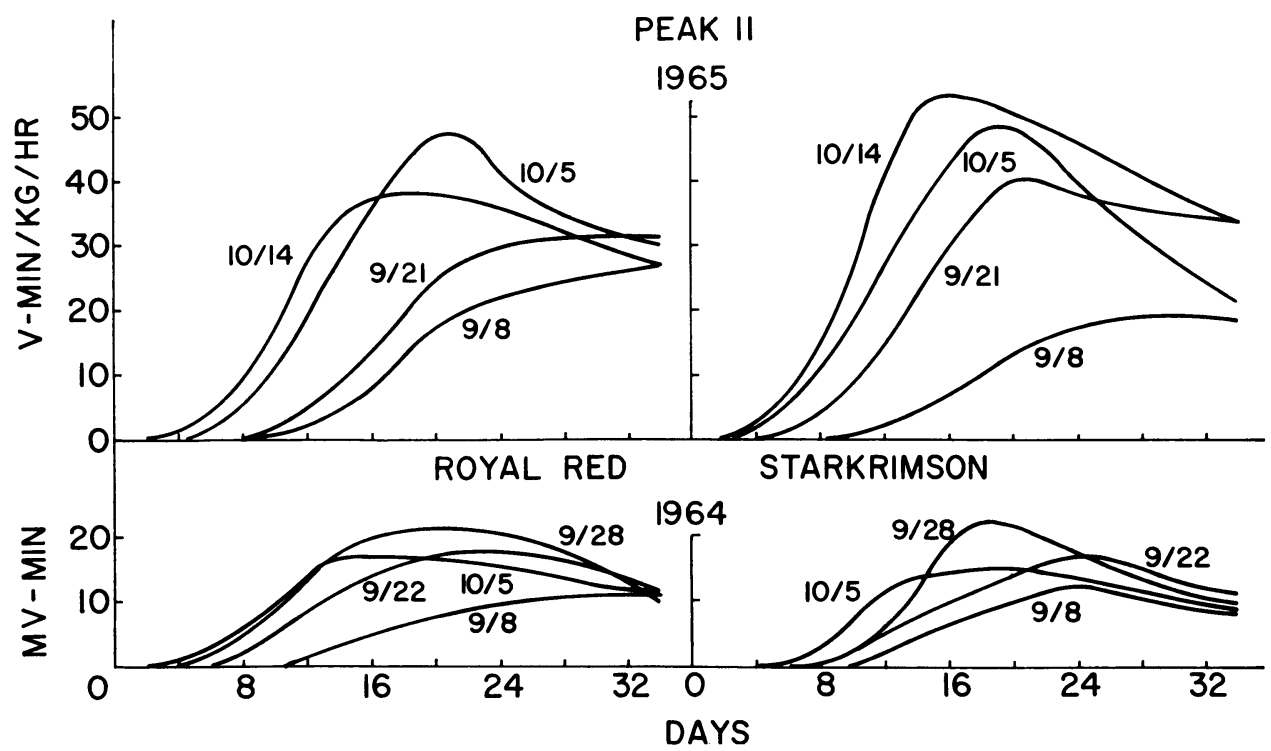

Fig. 4. Production curves for the volatile at Peak 11 as determined on the DEGS column in 1964 and the FFAP column in 1965 for Royal Red Delicious and Starkrimson shortly after the harvest dates indicated. 


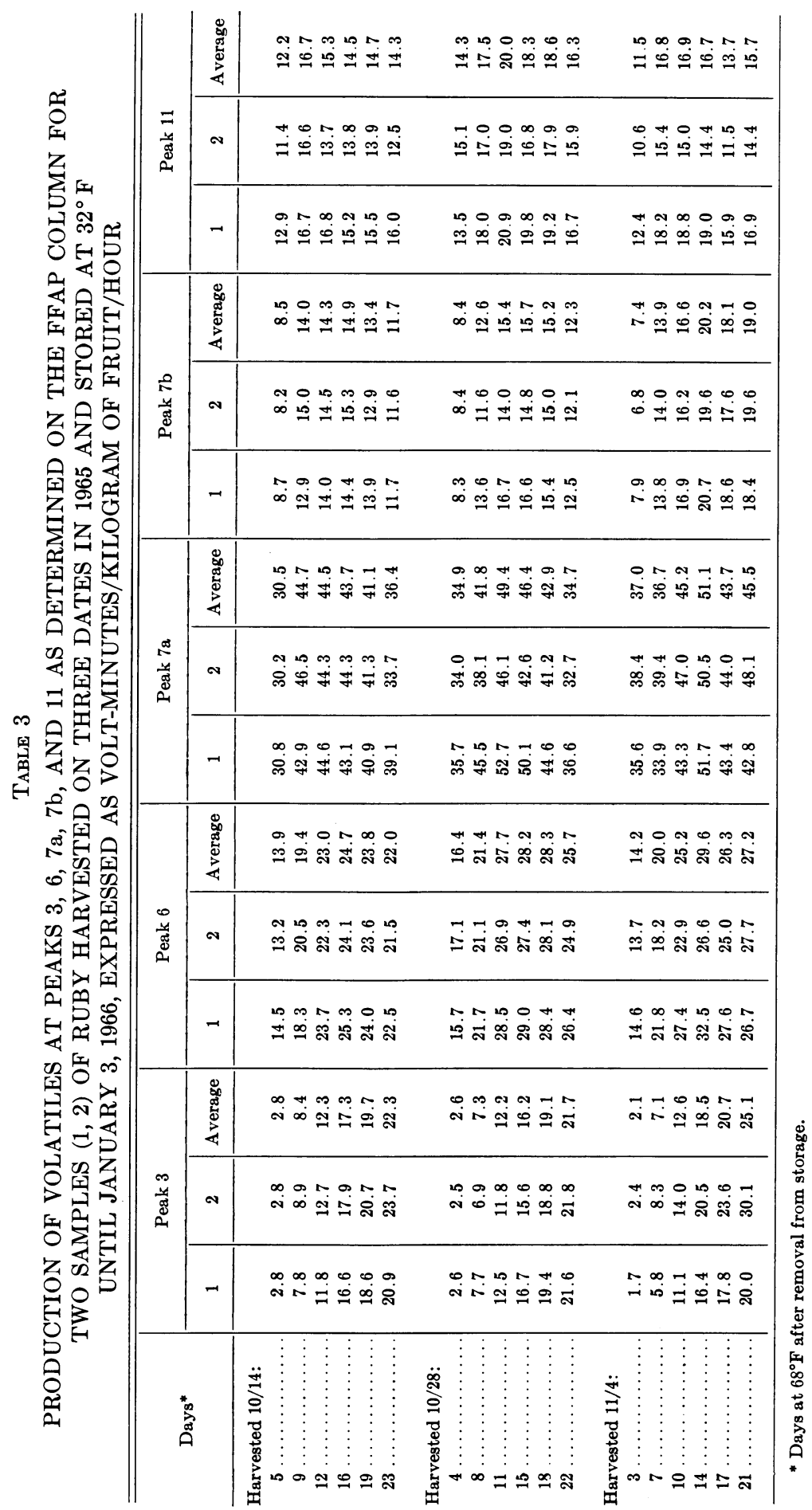




\begin{tabular}{|c|c|c|c|c|c|}
\hline \multirow{3}{*}{ 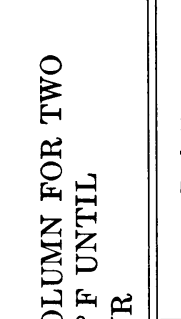 } & \multirow{3}{*}{ 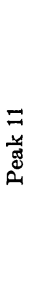 } & 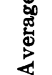 & 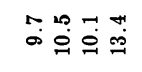 & 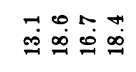 & 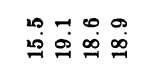 \\
\hline & & $\infty$ & 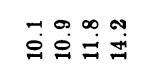 & 品 & 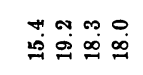 \\
\hline & & - & 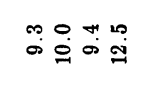 & 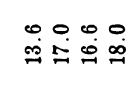 & 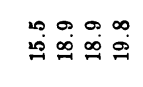 \\
\hline 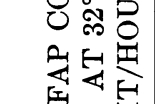 & & 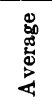 & 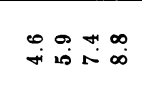 & 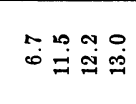 & 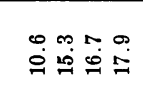 \\
\hline 国絪贵 & 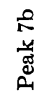 & N & 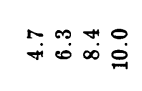 & 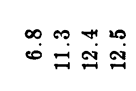 & 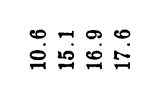 \\
\hline ○是要 & & - & ن & 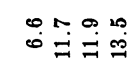 & 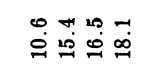 \\
\hline 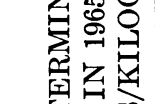 & & 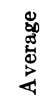 & 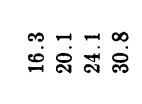 & 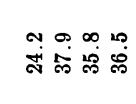 & 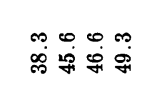 \\
\hline 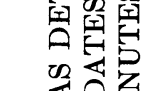 & 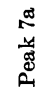 & N & 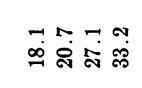 & 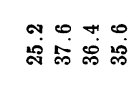 & 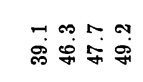 \\
\hline 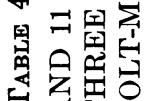 & & - & 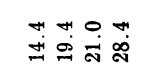 & 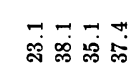 & 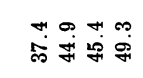 \\
\hline 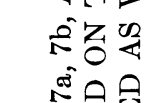 & & 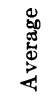 & 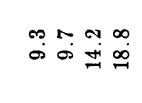 & 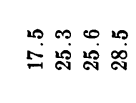 & 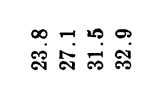 \\
\hline 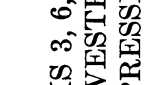 & $\begin{array}{l}0 \\
\text { ज्ञ } \\
\text { م }\end{array}$ & $\omega$ & 足邑 & 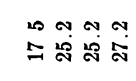 & 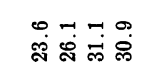 \\
\hline 勿 & & - & 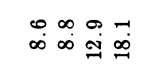 & 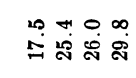 & 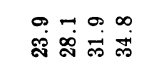 \\
\hline 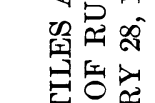 & & 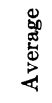 & 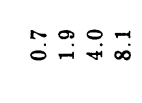 & 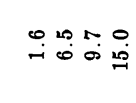 & 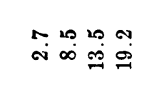 \\
\hline 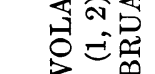 & $\begin{array}{l}\infty \\
\text { 常 } \\
0\end{array}$ & a & 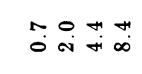 & 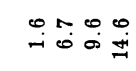 & 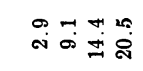 \\
\hline 品 & & - & 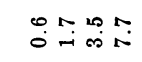 & 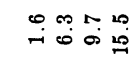 & 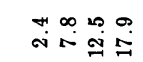 \\
\hline $\begin{array}{l}0 \\
0 \\
0 \\
0 \\
0.1\end{array}$ & & & 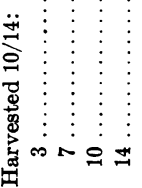 & 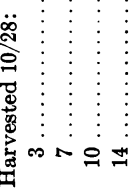 & 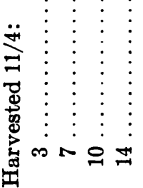 \\
\hline
\end{tabular}




\begin{tabular}{|c|c|c|c|c|c|c|}
\hline \multirow{3}{*}{ 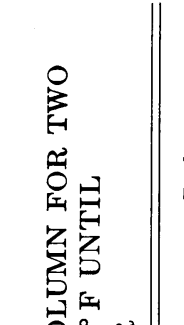 } & \multirow{3}{*}{$\begin{array}{l}\vec{Z} \\
\text { 离 } \\
\text { a }\end{array}$} & 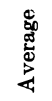 & 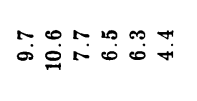 & 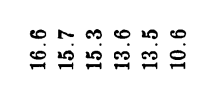 & 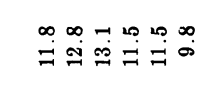 & 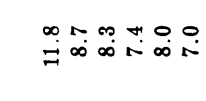 \\
\hline & & ๙ & 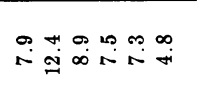 & 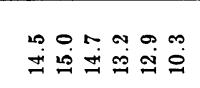 & 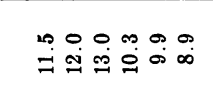 & تص \\
\hline & & - & 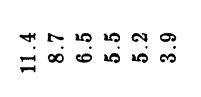 & 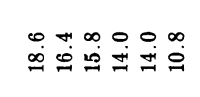 & 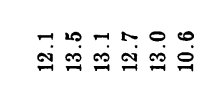 & 包 \\
\hline 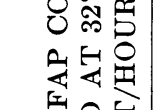 & & 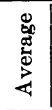 & 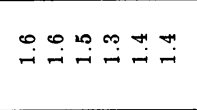 & 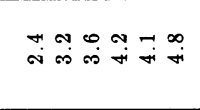 & 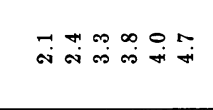 & 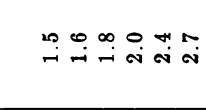 \\
\hline & $\begin{array}{l}\text { 온 } \\
\text { 岛 }\end{array}$ & ه & 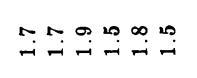 & 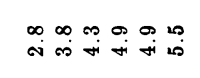 & 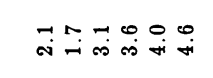 & تِّ تِ \\
\hline 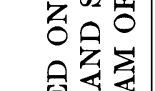 & & - & تُ & 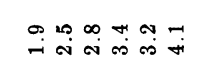 & 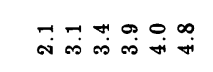 & 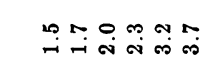 \\
\hline 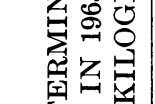 & & 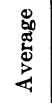 & 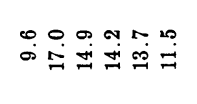 & 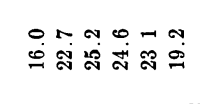 & 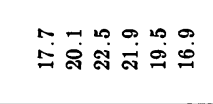 & 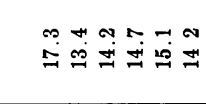 \\
\hline 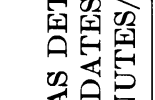 & 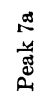 & $\sim$ & 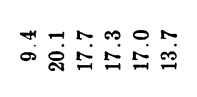 & 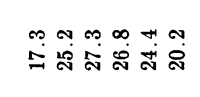 & 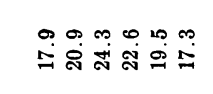 & 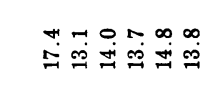 \\
\hline 国百宫是 & & - & 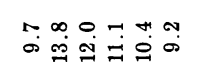 & 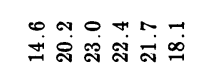 & 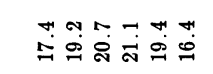 & 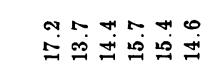 \\
\hline 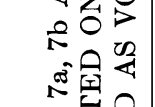 & & 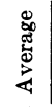 & 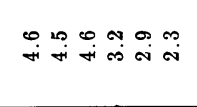 & 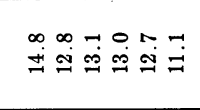 & 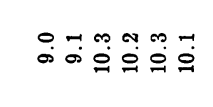 & $\begin{array}{ccc}7 \\
0 \\
0\end{array}$ \\
\hline 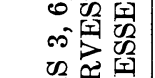 & o & N & 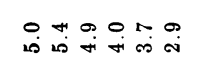 & 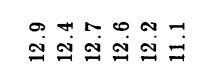 & 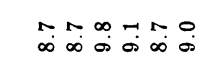 & 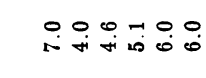 \\
\hline 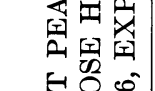 & & - & Fi & 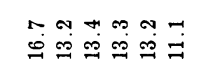 & 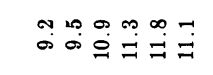 & 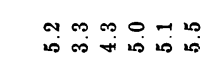 \\
\hline 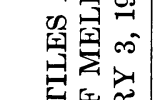 & & 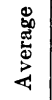 & $0_{0}^{\infty} 0$ & 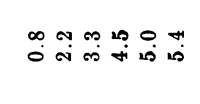 & 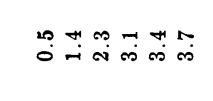 & تَّت \\
\hline 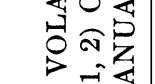 & 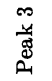 & ه & 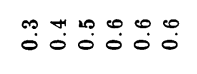 & 象 & 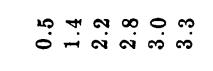 & ن \\
\hline 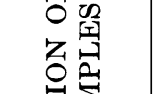 & & - & $: 0$ & 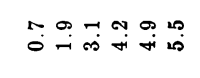 & $\underset{0}{+}$ & $\overrightarrow{0}$ \\
\hline 足 & & & 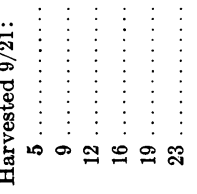 & 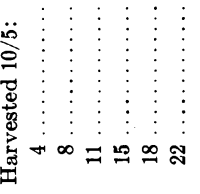 & 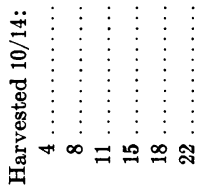 & 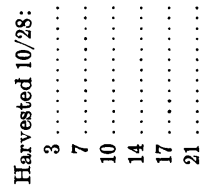 \\
\hline
\end{tabular}




\begin{tabular}{|c|c|c|c|c|c|c|}
\hline \multirow{16}{*}{ 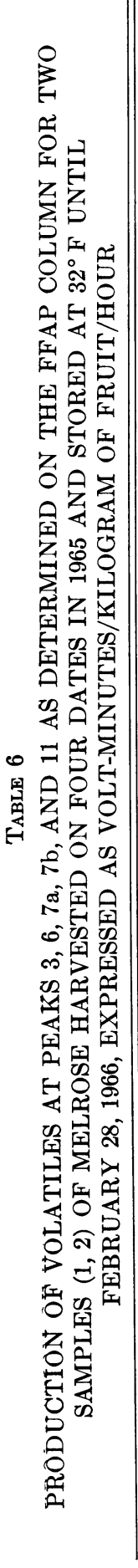 } & \multirow{3}{*}{$\begin{array}{l}\vec{z} \\
\text { 总 } \\
\text { مै }\end{array}$} & 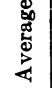 & 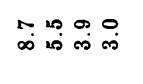 & 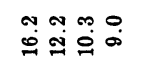 & 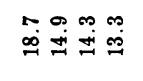 & 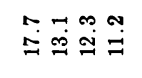 \\
\hline & & $\sim$ & 的 & 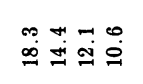 & $\begin{array}{l}\infty \\
\infty \\
\infty \\
\infty\end{array}$ & 它怘苔 \\
\hline & & - & 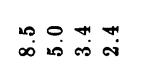 & 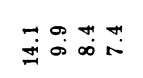 & 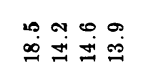 & 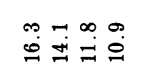 \\
\hline & \multirow{3}{*}{ 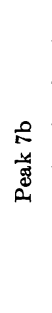 } & 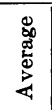 & 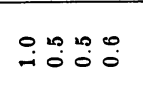 & 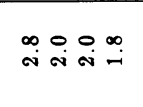 & 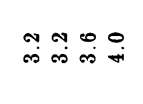 & 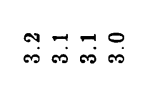 \\
\hline & & $\sim$ & $\exists=0000$ & 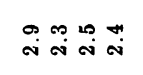 & 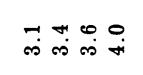 & 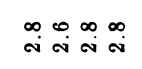 \\
\hline & & - & 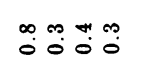 & 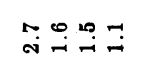 & 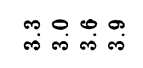 & 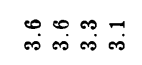 \\
\hline & \multirow{3}{*}{ 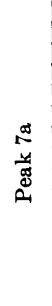 } & 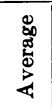 & 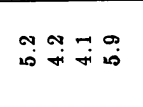 & 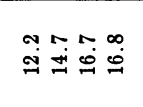 & 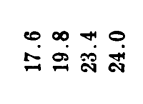 & 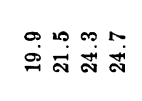 \\
\hline & & N & 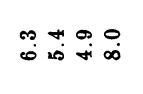 & 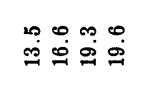 & 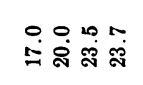 & 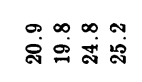 \\
\hline & & - & 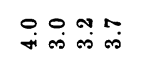 & $\begin{array}{l}\infty \\
\stackrel{0}{0} \cong 0\end{array}$ & 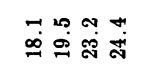 & 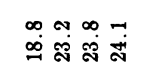 \\
\hline & \multirow{3}{*}{ 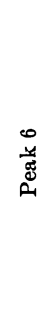 } & 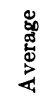 & $\stackrel{\circ}{+} \stackrel{\infty}{\sim} \underset{\sim}{\sim} \stackrel{\infty}{\sim}$ & 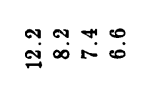 & 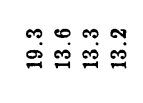 & 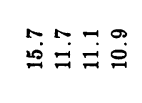 \\
\hline & & $\sim$ & 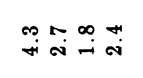 & فำ & 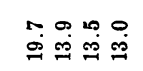 & $\begin{array}{l}\infty \\
\dot{y} \\
\dot{0}\end{array}$ \\
\hline & & - & $\stackrel{0}{\infty} \stackrel{0}{\sim} \stackrel{\infty}{\sim}$ & 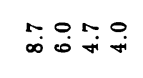 & 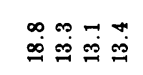 & 品品 \\
\hline & \multirow{3}{*}{ 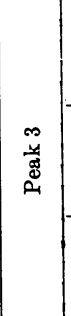 } & 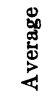 & $\overrightarrow{0} \overrightarrow{0} \overrightarrow{0} \overrightarrow{0}$ & 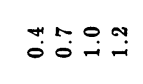 & 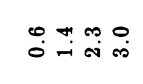 & 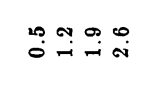 \\
\hline & & a & $\overrightarrow{0} 0.70$ & 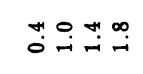 & 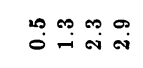 & 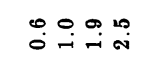 \\
\hline & & - & $\overrightarrow{0} 0 \overrightarrow{0}=\overrightarrow{0}$ & $\begin{array}{lll}H \\
0\end{array}$ & 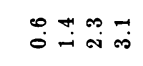 & $\ddot{0}$ \\
\hline & & 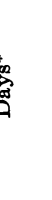 & 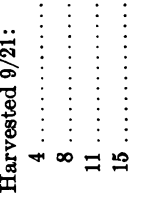 & 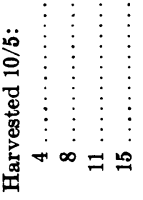 & 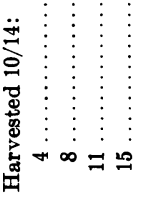 & 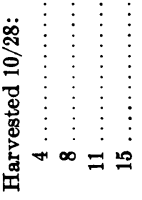 \\
\hline
\end{tabular}




\section{RESULTS AND DISCUSSION}

Figure 5 shows chromatograms typical of samples of the volatiles from Starkrimson and Royal Red Delicious as developed with the two different columns. Peaks 7 and 9 on the chromatograms with the column coated with diethylene glycol succinate (DEGS) separated into pairs of peaks, $7 a-7 b$ and $9 a-9 b$, with the more sensitive column coated with FFAP.

Identifying volatiles. Relative retention times for 26 known alcohols and esters and for various apple volatiles determined on the two columns are listed in table 7 . Close agreement of both columns in relative retention times for a known compound, and an unknown component of the apple volatiles, provides some evidence as to the identity of the unknown. Values for the volatile component responsible for peak 1 coincide exactly with those for ethyl acetate, and values for peak 6 are identical with those for butyl acetate, the reference compound. There is close agreement between peak 2 and ethyl propionate, peak 3 and propyl acetate, peak 4 and isobutylacetate, peak 5 and propyl propionate, peak 8 and pentyl acetate, peak 10 and ethyl caproate, and peak 11 and hexyl acetate.

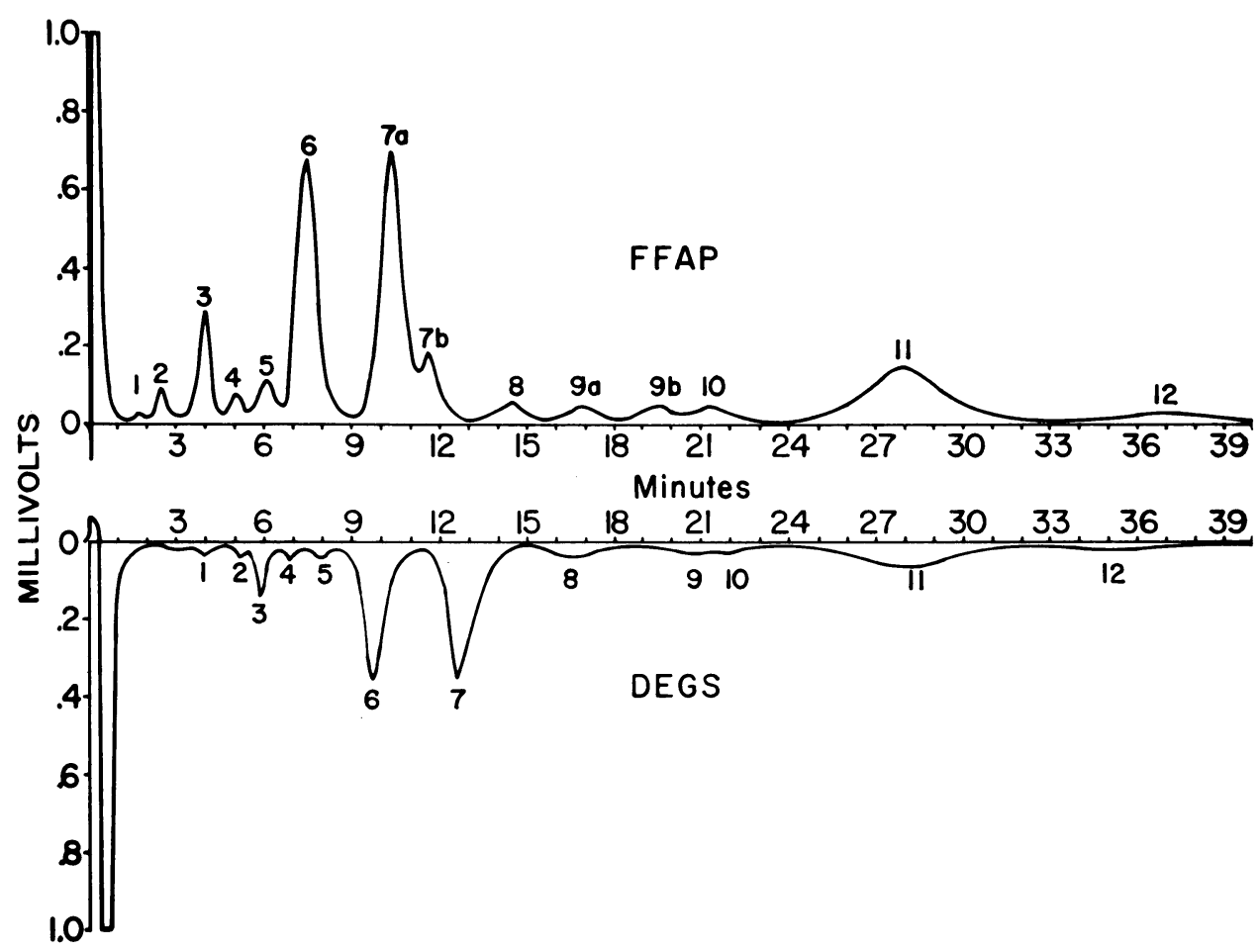

Fig. 5. Typical gas chromatograms of volatiles from mature Starkrimson apples at the respiratory climacteric, as measured on two columns, one coated with diethylene glycol succinate (DEGS) and the other with FFAP, October 1965 (attenuation 8x). 
TABLE 7

RELATIVE RETENTION TIMES (RRT) FOR PEAKS FROM UNIDENTIFIED APPLE VOLATILES (PEAKS 1-12), AND FROM KNOWN ALCOHOLS AND ESTERS ON TWO CHROMATOGRAPHIC COLUMNS

\begin{tabular}{|c|c|c|c|c|c|}
\hline \multirow{2}{*}{ Compounds and Peaks } & \multicolumn{2}{|c|}{ Column* } & \multirow{2}{*}{ Compounds and Peaks } & \multicolumn{2}{|c|}{ Column* } \\
\hline & DEGS & FFAP & & DEGS & FFAP \\
\hline & \multicolumn{2}{|c|}{$\mathbf{R R T}$} & & \multicolumn{2}{|c|}{ RRT } \\
\hline Methyl acetate........ & 0.32 & 0.26 & Butanol $\uparrow \ldots \ldots \ldots \ldots \ldots \ldots \ldots \ldots$ & 1.21 & 1.53 \\
\hline Isopropyl acetate $. . . \ldots .$. & 0.39 & 0.34 & Propyl butyrate .................... & 1.23 & 1.37 \\
\hline Peak $1 \ldots \ldots \ldots \ldots \ldots$ & 0.40 & 0.33 & Peak $7 \ldots \ldots \ldots \ldots \ldots \ldots \ldots \ldots \ldots$ & 1.29 & $\ldots$ \\
\hline Ethyl acetate $\ldots . . \ldots \ldots$ & 0.40 & 0.33 & Peak $7 a \ldots \ldots \ldots \ldots \ldots \ldots \ldots \ldots \ldots$ & $\ldots$ & 1.39 \\
\hline Ethanol $\dagger \ldots \ldots \ldots \ldots \ldots$ & 0.47 & 0.52 & Peak $7 \mathrm{~b} . \ldots \ldots \ldots \ldots \ldots \ldots \ldots \ldots \ldots \ldots \ldots \ldots \ldots$ & $\ldots$ & 1.55 \\
\hline Isopropyl propionate... & 0.51 & 0.50 & Isopentyl acetatet..................... & 1.29 & 1.38 \\
\hline Peak 2.............. & 0.54 & 0.47 & Peak $8 \ldots \ldots \ldots \ldots \ldots \ldots \ldots \ldots$ & 1.69 & 1.93 \\
\hline Ethyl propionate $\nmid \ldots \ldots \ldots$ & 0.54 & 0.49 & Isopentanol $\nmid \ldots \ldots \ldots \ldots \ldots \ldots \ldots \ldots \ldots$ & 1.69 & 2.24 \\
\hline Peak $3 \ldots \ldots \ldots \ldots$ & 0.61 & 0.53 & Pentyl acetate $\nmid \ldots \ldots \ldots \ldots \ldots \ldots \ldots \ldots$ & 1.70 & 1.92 \\
\hline Propyl acetate . . . . . . & 0.61 & 0.54 & Isopentyl propionate $\ldots \ldots \ldots \ldots \ldots \ldots$ & 1.78 & 2.12 \\
\hline Methyl butyrate...... & 0.64 & 0.59 & Butyl butyrate $\nmid \ldots \ldots \ldots \ldots \ldots \ldots \ldots$ & 2.05 & 2.55 \\
\hline Peak $4 \ldots \ldots \ldots \ldots$ & 0.70 & 0.68 & Peak $9 \ldots \ldots \ldots \ldots \ldots \ldots \ldots \ldots \ldots \ldots \ldots \ldots \ldots$ & 2.12 & $\ldots$ \\
\hline Propanol†........... & 0.71 & 0.78 & 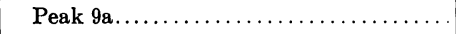 & $\ldots$ & 2.27 \\
\hline Isobutyl acetate........ & 0.72 & 0.68 & Peak $9 \mathrm{~b} . \ldots \ldots \ldots \ldots \ldots \ldots \ldots \ldots \ldots \ldots \ldots \ldots \ldots \ldots$ & $\ldots$ & 2.59 \\
\hline Ethyl butyrate $f . . . \ldots \ldots$ & 0.79 & 0.79 & Pentanol $\nmid \ldots \ldots \ldots \ldots \ldots \ldots \ldots \ldots \ldots \ldots$ & 2.14 & 3.02 \\
\hline Peak 5............ & 0.80 & 0.83 & Ethyl caproate $\nmid \ldots \ldots \ldots \ldots \ldots \ldots \ldots$ & 223 & 2.82 \\
\hline Propyl propionate...... & 0.82 & 0.83 & Peak $10 \ldots \ldots \ldots \ldots \ldots \ldots \ldots \ldots \ldots$ & 2.25 & 2.83 \\
\hline Isobutanol $\nmid \ldots \ldots \ldots \ldots$ & 0.89 & 1.04 & Hexyl acetate $f . . \ldots \ldots \ldots \ldots \ldots \ldots \ldots$ & 2.89 & 3.67 \\
\hline Isobutyl propionate $\nmid \ldots . .$. & 0.98 & 1.05 & Peak $11 \ldots \ldots \ldots \ldots \ldots \ldots \ldots \ldots \ldots$ & 2.91 & 3.71 \\
\hline Peak $6 \ldots \ldots \ldots \ldots \ldots$ & 1.00 & 1.00 & Pentyl butyrate..................... & 3.52 & 4.84 \\
\hline Butyl acetate $\nmid \ldots \ldots \ldots \ldots \ldots \ldots \ldots \ldots$ & 1.00 & 1.00 & Peak $12 \ldots \ldots \ldots \ldots \ldots \ldots \ldots \ldots \ldots \ldots$ & 3.60 & 4.96 \\
\hline
\end{tabular}

* DEGS column coated with diethylene glycol succinate; FFAP is a manufacturer's designation for other coating (seo

† Compounds previously identified from apples (Huelin, 1952; MacGregor et al., 1964; Stackenbrok, 1951; Thompson, 1951; Thompson and Huelin, 1951).

Peaks 7 and 9 on the DEGS column represent a mixture of at least two components each, as separation into peaks $7 \mathrm{a}$ and $7 \mathrm{~b}$, and $9 \mathrm{a}$ and $9 \mathrm{~b}$, respectively, resulted with samples on the FFAP column. Without relative retention times on more than one column for comparison with those of known compounds, or without other evidence, no identification is certain for components of peaks $7 \mathrm{a}, 7 \mathrm{~b}, 9 \mathrm{a}$ and $9 \mathrm{~b}$. However, in terms of the results on the FFAP column it appears that components of these peaks may be: 7a, isopentyl acetate; 7b, butanol; 9a, isopentanol; and $9 \mathrm{~b}$, butyl butyrate.

Maturity of samples. Peaks 3, 6, 7a, and 11 were most prominent among volatiles produced by Royal Red Delicious and Starkrimson in 1965 (fig. 5) and, as in 1964 (Brown et al., 1966), they were components most closely associated with maturity and ripeness. They were detected relatively early in each test run, attained maximum values at or shortly after the time apples reached the respiratory climacteric, and then declined as the apples became senescent. Most of the other, less prominent volatiles were first evident somewhat later in each test and continued to increase to the end of the run, by which time the apples usually showed evidence of senescence. The 1965 results for these prominent peaks are presented for two varieties; they are compared with similar data from the 1964 samples, and from the samples stored in 1965. Peak $7 \mathrm{~b}$ was less prominent than 7a, but it also appears to be associated 


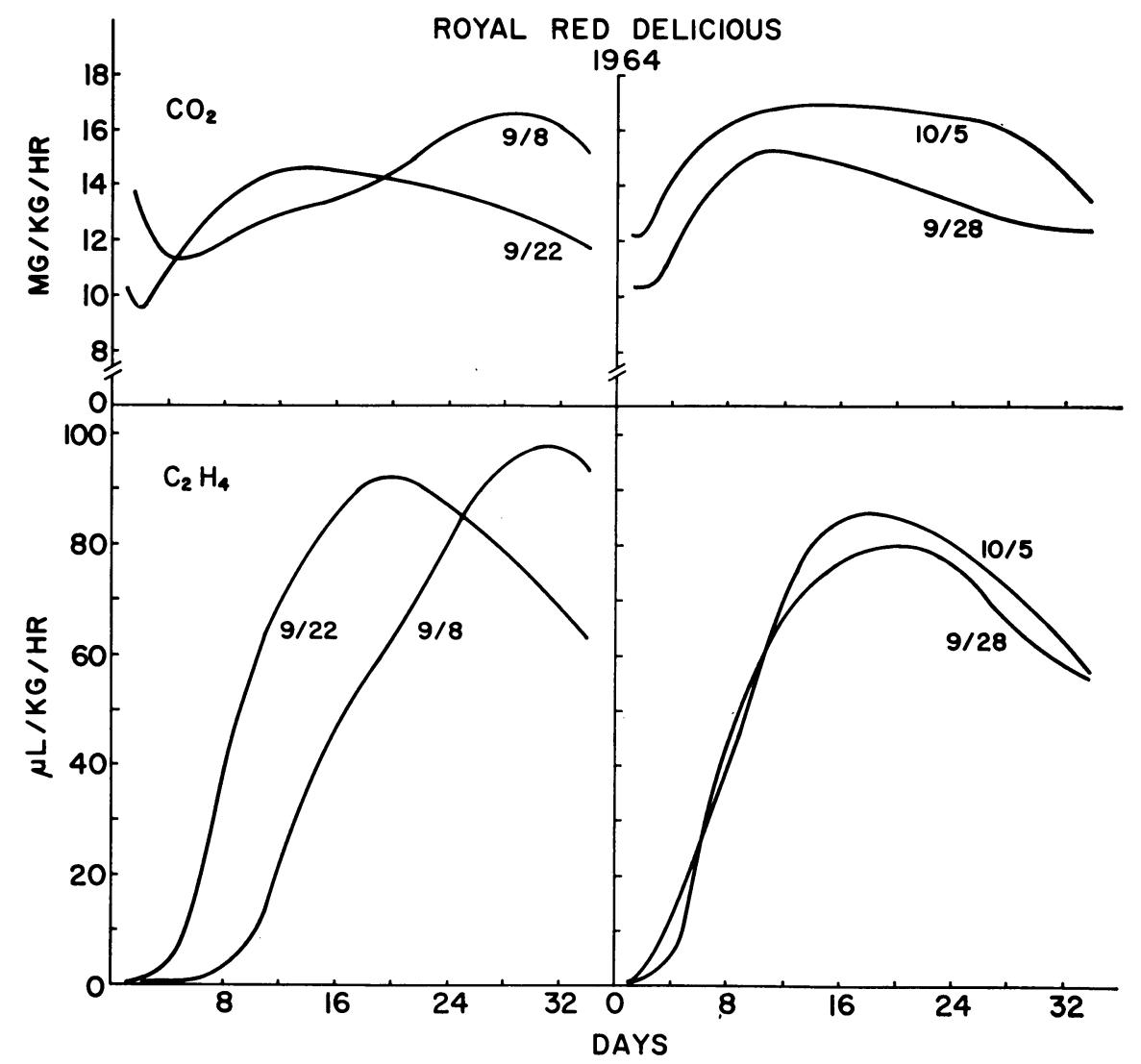

Fig. 6. Rates of $\mathrm{CO}_{2}$ and $\mathrm{C}_{2} \mathrm{H}_{4}$ production for Royal Red Delicious in 1964 as determined at $68^{\circ}$ $\mathrm{F}$ over a 36-day period beginning shortly after harvest dates indicated. (Vertical scale not complete from 0 to $8 \mathrm{mg} / \mathrm{kg} / \mathrm{hr}$.)

with maturation and ripening processes-therefore, data for peak $7 \mathrm{~b}$ are considered along with those of $7 \mathrm{a}$ for peak 7 .

Brown et al. (1966) reported that Royal Red Delicious matured slightly ahead of Starkrimson in 1964 in an orchard near Sebastopol. A similar difference in maturity between the two varieties in the Watsonville orchard in 1964 is indicated, as most Royal Red samples from that orchard reached the climacteric in $\mathrm{CO}_{2}$ and $\mathrm{C}_{2} \mathrm{H}_{4}$ production just slightly earlier than did Starkrimson samples harvested on the same dates (figs. 6 and 7), and they were generally higher in soluble solids (table 8 ). The 1964 firmness data are not conclusive and do not indicate such maturity difference in the two varieties.

Royal Red Delicious and Starkrimson were nearly alike in maturity in $\mathbf{1 9 6 5}$ at Watsonville. Comparable samples of the two varieties did not differ consistently as to time in reaching the climacteric in $\mathrm{CO}_{2}$ and $\mathrm{C}_{2} \mathrm{H}_{4}$ production (figs. 8 and 9), nor did they differ much in soluble solids or firmness values (table 8). The first samples (September 8) were clearly immature for both varieties in each year, because from 28 to 31 days were required to reach the climacteric in $\mathrm{CO}_{2}$ and $\mathrm{C}_{2} \mathrm{H}_{4}$ production. The relatively low soluble solids values of 9.2 and 10.6 for these samples are a further indication of their immaturity. 


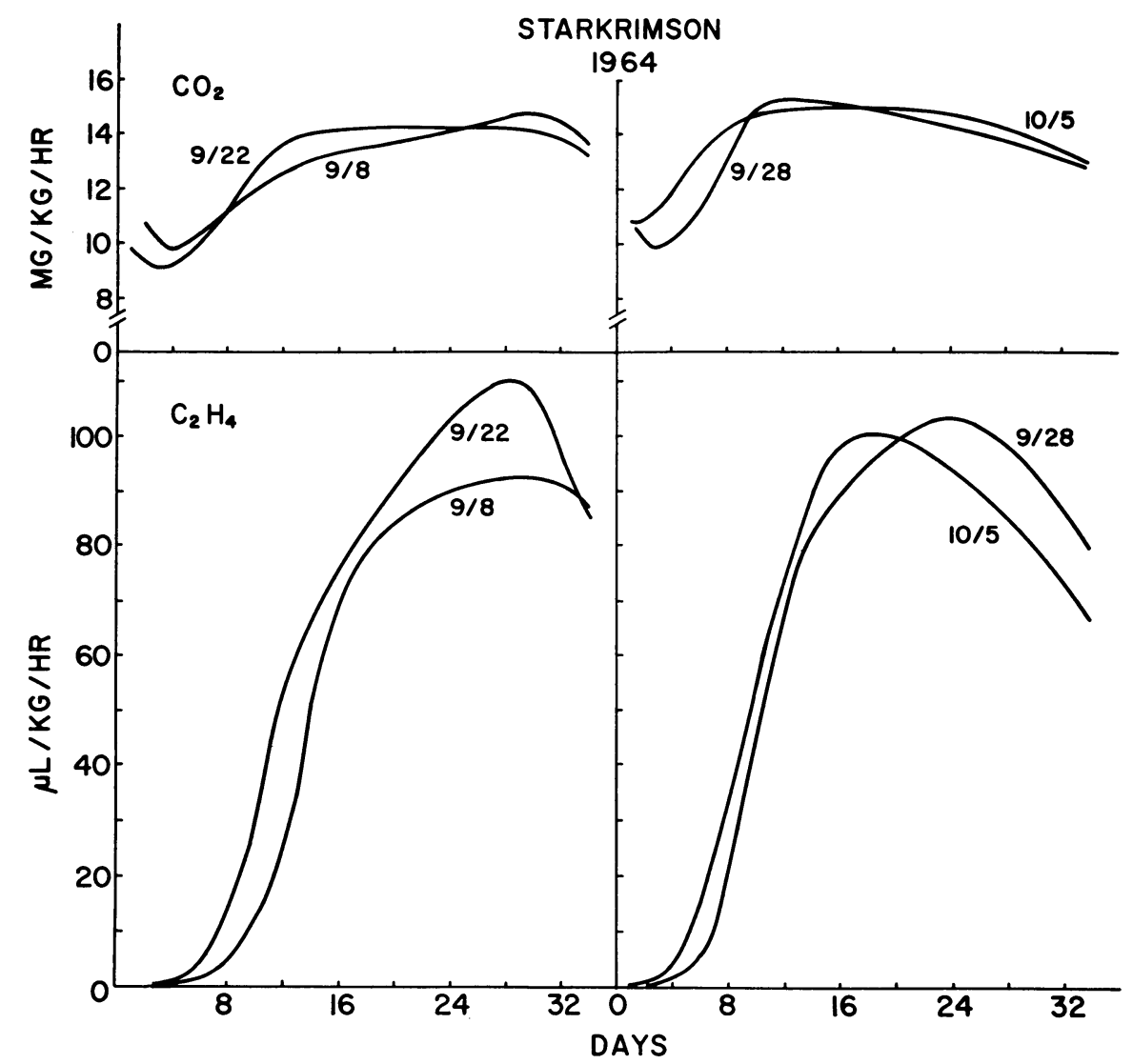

Fig. 7. Rates of $\mathrm{CO}_{2}$ and $\mathrm{C}_{2} \mathrm{H}_{4}$ production for Starkrimson in 1964 as determined at $68^{\circ} \mathrm{F}$ over a 36 -day period beginning shortly after the harvest dates indicated.

Increasing maturity of successive samples for both varieties in both years is indicated by a trend toward an earlier climacteric the later the harvest, and by the slight increase in soluble solids with each successive sampling date. Maximum $\mathrm{C}_{2} \mathrm{H}_{4}$ production also occurred successively earlier the later the harvest, reflecting the more advanced maturity of the later samples. Starkrimson attained higher levels of $\mathrm{C}_{2} \mathrm{H}_{4}$ production in both years than did Royal Red Delicious. There was no consistent relationship within either variety between maximum rates of $\mathrm{C}_{2} \mathrm{H}_{4}$ production and the dates of sampling or maturity of fruit.

Volatiles and fruit maturity. The relation of fruit maturity to production of volatiles in Royal Red Delicious and Starkrimson was similar to that evidenced in the $\mathrm{CO}_{2}$ and $\mathrm{C}_{2} \mathrm{H}_{4}$ production curves. In general, with both varieties in both years, maximum production of each volatile after harvest occurred successively earlier the later the harvest and the more mature the apples (figs. $1,2,3$ and 4). There was also a tendency with peaks 6 and 11 volatiles in particular for maximum rates of production to be higher the later the harvest (figs. 2 and 4 ). This trend was not shown consistently in both varieties for all sample dates in determinations made shortly after harvest, but it was marked and generally shown by samples after storage, particularly those stored until February (figs. 10, 11, 12 and 13). 
TABLE 8

AVERAGE FIRMNESS AND SOLUBLE SOLIDS VALUES FOR STARKRIMSON AND ROYAL RED DELICIOUS APPLES AT DIFFERENT DATES OF PICKING IN 1964 AND 1965 AND AFTER STORAGE IN 1965

\begin{tabular}{|c|c|c|c|c|c|c|c|c|c|}
\hline \multicolumn{3}{|c|}{1964} & \multicolumn{7}{|c|}{1965} \\
\hline \multirow{3}{*}{ Harvest date } & \multirow{2}{*}{\multicolumn{2}{|c|}{ Harvest samples }} & \multirow{3}{*}{$\underset{\text { date }}{\text { Harvest }}$} & \multirow{2}{*}{\multicolumn{2}{|c|}{ Harvest samples }} & \multicolumn{4}{|c|}{ Samples stored to: } \\
\hline & & & & & & \multicolumn{2}{|c|}{$11 / 28 / 65$} & \multicolumn{2}{|c|}{$2 / 7 / 65$} \\
\hline & $\begin{array}{l}\text { Firm- } \\
\text { ness } \\
\text { (lb.) }\end{array}$ & $\begin{array}{c}\text { Soluble } \\
\text { solids } \\
\text { (per } \\
\text { cent) }\end{array}$ & & $\begin{array}{l}\text { Firm- } \\
\text { ness } \\
\text { (lb.) }\end{array}$ & $\begin{array}{c}\text { Soluble } \\
\text { solids } \\
\text { (per } \\
\text { cent) }\end{array}$ & $\begin{array}{c}\text { Firm- } \\
\text { ness } \\
\text { (lb.) }\end{array}$ & $\begin{array}{l}\text { Soluble } \\
\text { solids } \\
\text { (per } \\
\text { cent) }\end{array}$ & $\begin{array}{l}\text { Firm- } \\
\text { ness } \\
\text { (lb.) }\end{array}$ & $\begin{array}{c}\text { Soluble } \\
\text { solids } \\
\text { (per I } \\
\text { cent) }\end{array}$ \\
\hline \multicolumn{10}{|l|}{ Royal Red Delicious } \\
\hline $9 / 8 \ldots \ldots \ldots \ldots \ldots$ & 19.7 & 10.4 & $9 / 8$ & 22.8 & 10.6 & 20.0 & 13.0 & 20.3 & 13.4 \\
\hline $9 / 22 \ldots \ldots \ldots \ldots$ & 19.6 & 11.8 & $9 / 21$ & 20.8 & 11.0 & 20.1 & 13.0 & 18.2 & 13.6 \\
\hline $9 / 28$ & 20.0 & 12.8 & $10 / 5$ & 21.4 & 11.2 & 20.3 & 13.4 & 16.9 & 14.0 \\
\hline $10 / 5 \ldots \ldots$ & 20.3 & 13.0 & $10 / 14$ & 19.7 & 11.6 & 20.6 & 13.4 & 17.4 & 14.8 \\
\hline \multicolumn{10}{|l|}{ Starkrimson } \\
\hline $9 / 8 \ldots \ldots$ & 21.6 & 9.2 & $9 / 8$ & 21.4 & 10.0 & 20.6 & 12.8 & 18.0 & 12.8 \\
\hline $9 / 22 \ldots \ldots$ & 19.5 & 10.0 & $9 / 21$ & 20.7 & 11.0 & 20.3 & 12.8 & 17.0 & 12.6 \\
\hline $9 / 28$ & 19.7 & 10.8 & $10 / 5$ & 20.5 & 11.2 & 18.9 & 13.0 & 16.4 & 12.8 \\
\hline $10 / 5 \ldots \ldots \ldots \ldots \ldots$ & 19.2 & 11.8 & $10 / 14$ & 20.0 & 12.0 & 19.6 & 13.0 & 16.5 & 13.0 \\
\hline
\end{tabular}

Thompson and Huelin (1951) also reported that early picking reduced ester production.

Volatiles were not produced in measurable quantities as soon after harvest by earlier and less mature samples as they were by apples from later harvests. For example, in 1964 the first measurable quantities of the peak 3 volatile were produced within 11 to 15,8 to 12 , 7 to 11 , and 4 to 8 days after the September 8, 22, 28, and October 5 harvests, respectively (fig. 1 ; table 1 ). Similar relationships between the onset of measurable production and date of harvest were shown in both years and by other volatiles also (figs. 1, 2, 3 and 4; tables 1 and 2). Relationships among production curves, in any year and for any variety, in onset and initial rise in volatile production were essentially alike for all of the volatiles, including $\mathrm{C}_{2} \mathrm{H}_{4}$. For example, the pairing of the September 8 and 21 and the October 5 and 14 curves for the peak 3 volatile from Royal Red in 1965 (fig. 1), also shows consistently in the curves for $\mathrm{C}_{2} \mathrm{H}_{4}$ and the peak $6,7 \mathrm{a}, 7 \mathrm{~b}$, and 11 volatiles (figs. $2,3,4$ and 8 ). The same pairing also is evident in the curves from most of the stored samples as well (figs. 10, 11, 12, 13 and 14).

Varietal differences. Differences in maturity between Royal Red Delicious and Starkrimson were also indicated by volatiles. In 1964, volatiles from Royal Red usually attained maximums of production 3 or 4 days earlier than those from Starkrimson, thus reflecting the trend toward earlier maturity of Royal Red in 1964. Difference in maturity is shown even more clearly by differences between varieties in onset and initial rise in production of volatiles. With the possible exception of the first harvest date, production of volatiles from Royal Red began 3 to 4 days sooner than it did from Starkrimson in 1964 (figs. 1, 2, 3 and 4). For 1965 the reverse-a slightly earlier maturity of Starkrimson - is indicated; volatiles from Starkrimson in 1965 frequently reached maximum production earlier than did those from Royal Red. Again, 


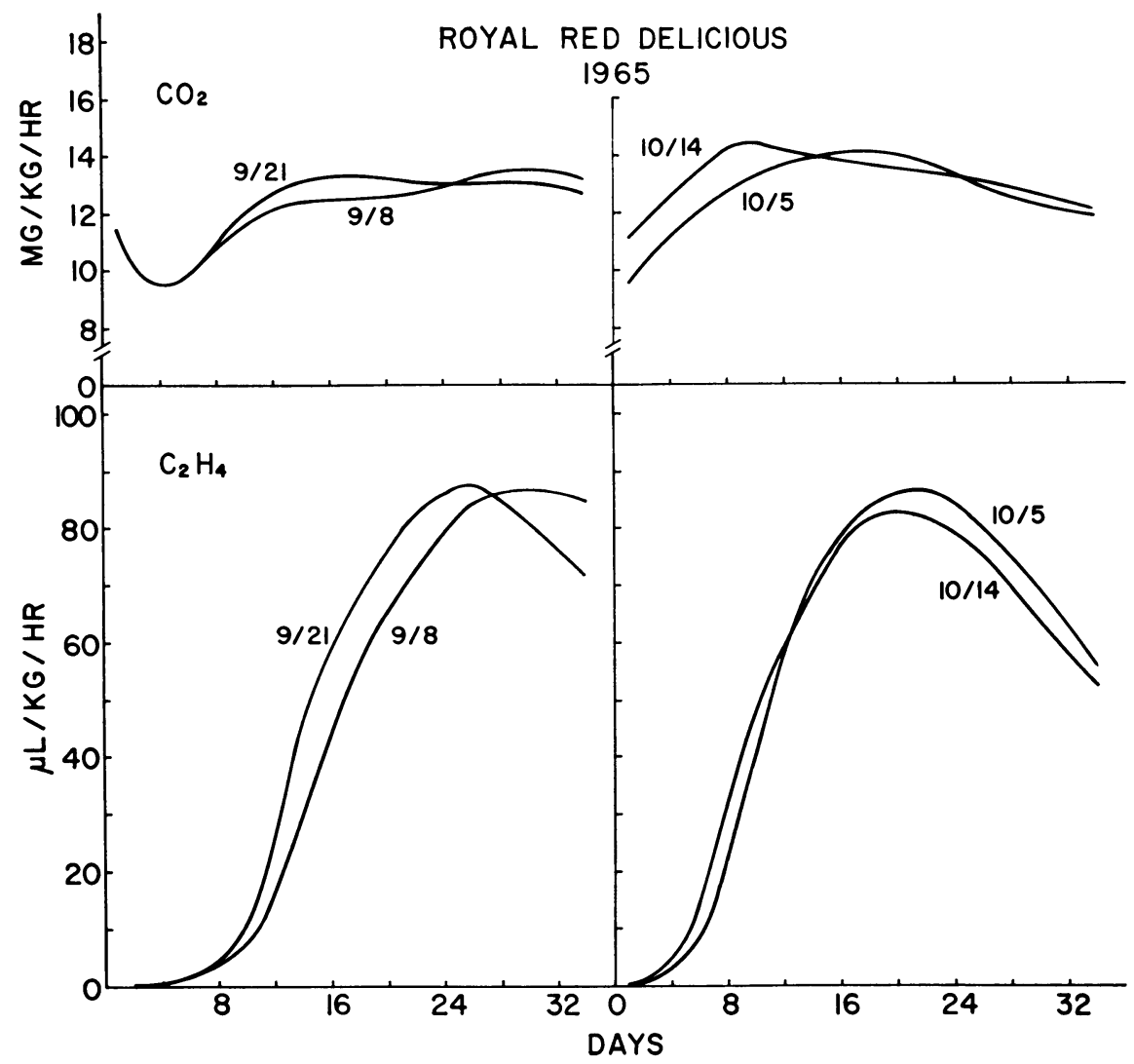

Fig. 8. Rates of $\mathrm{CO}_{2}$ and $\mathrm{C}_{2} \mathrm{H}_{4}$ production for Royal Red Delicious in 1965 as determined at $68^{\circ} \mathrm{F}$ over a 36 -day period beginning shortly after the harvest dates indicated.

onset and initial rise in production of volatiles is a better index of a difference between the two varieties. With the exception of the first harvest, production of volatiles from Starkrimson in 1965 began 3 to 4 days sooner and increased initially more rapidly than it did from Royal Red (figs. 1, 2, 3 and 4).

Production patterns for volatiles from Royal Red Delicious and Starkrimson sampled at Watsonville, were similar, indicating the common origin of these two sports. However, there were differences with some volatiles, similar to the higher rate of $\mathrm{C}_{2} \mathrm{H}_{4}$ production by Starkrimson, which appear to differentiate the two varieties. For example, the peak 3 volatile reached higher maximums of production in
Starkrimson in both years (except for the earliest picking in 1965) than in Royal Red when apples were tested shortly after harvest (fig. 1). The differences were even more striking after storage at $32^{\circ} \mathrm{F}$ for $1 \frac{1}{2}$ to 5 months (fig. 10).

There were no consistent differences between Royal Red and Starkrimson in amount of volatiles produced at peak 6 in 1964 (fig. 2), but in 1965 Starkrimson showed higher rates of production at peak 6 than did Royal Red, except for the first harvest date (fig. 2). After storage until late November or early February, Starkrimson produced the peak 6 volatile at much higher rates than did Royal Red for all harvests (fig. 11). 


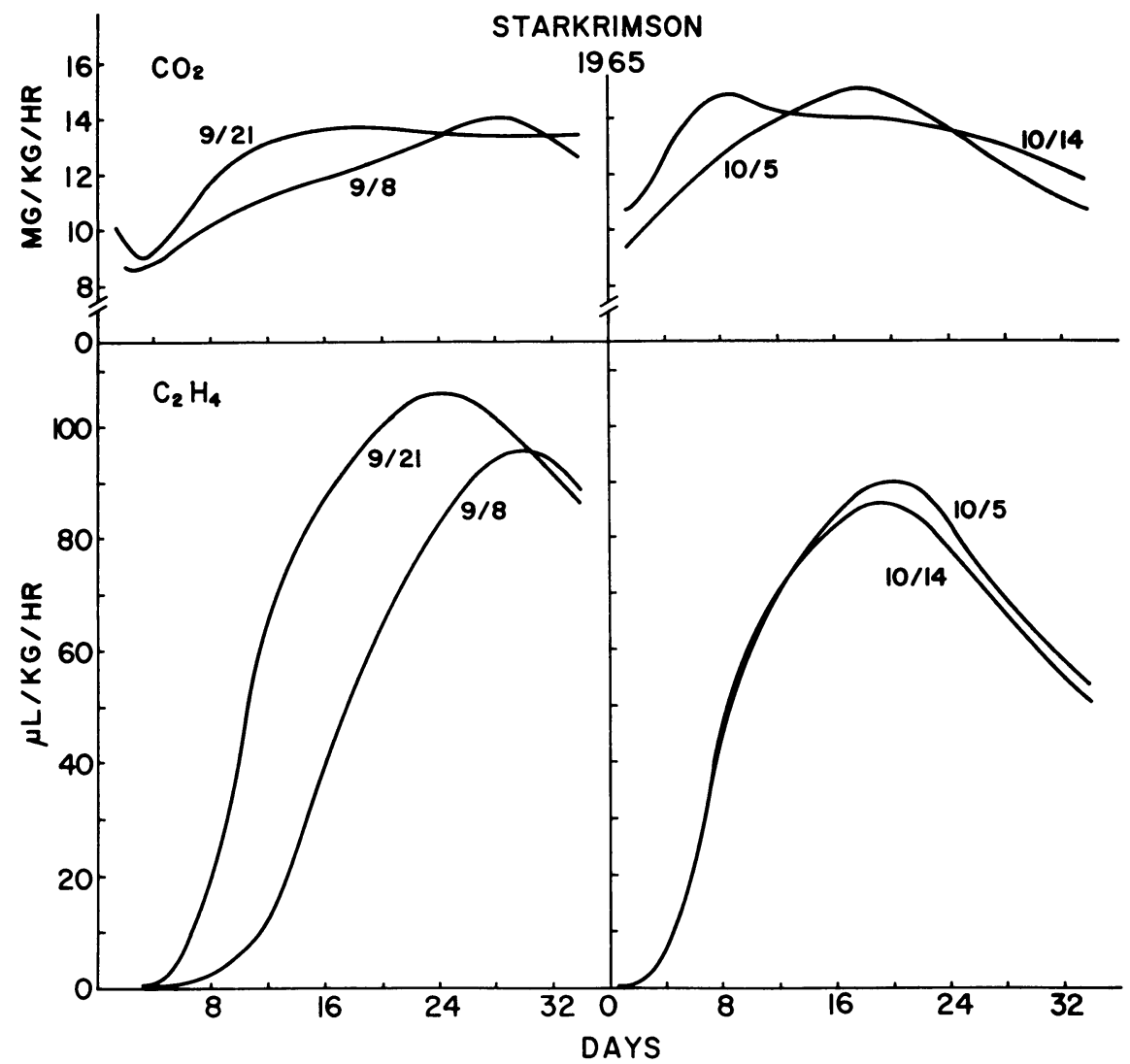

Fig. 9. Rates of $\mathrm{CO}_{2}$ and $\mathrm{C}_{2} \mathrm{H}_{4}$ production for Starkrimson in 1965 as determined at $68^{\circ} \mathrm{F}$ over a 36 -day period beginning shortly after the harvest dates indicated.

Production curves for peak 7 in 1964 (fig. 3) show slightly higher levels for Royal Red Delicious than for Starkrimson, the reverse of the relation between varieties for the other components. There were no consistent differences in 1965 between varieties in the production rates of rolatiles at peaks $7 \mathrm{a}$ and $7 \mathrm{~b}$ shortly after harvest (fig. 3), or following storage until late November (fig. 14). Following storage until February, however, Starkrimson produced peak $7 \mathrm{a}$ and peak $7 \mathrm{~b}$ volatiles at rates higher than those from Royal Red (fig. 12).

There were no consistent differences between the two varieties in production maximums of the peak 11 volatile in 1964, but in 1965 the maximums by
Starkrimson were equal to or higher than those by Royal Red, except for the earliest harvest (fig. 4). After storage in 1965, Starkrimson produced the volatile at higher rates than did Royal Red (fig. 13).

Effects of storage. The production rates of the volatiles from apples which had been in cold storage were related to the length of the storage period, as well as to the variety and date of harvest. For example, rates of production attained by the peak 3 volatile from the samples of both varieties stored until late November in 1965 were higher than from the samples tested shortly after harvest, except for the September 8 and September 21 pickings of Royal Red and the September 8 harvest of 


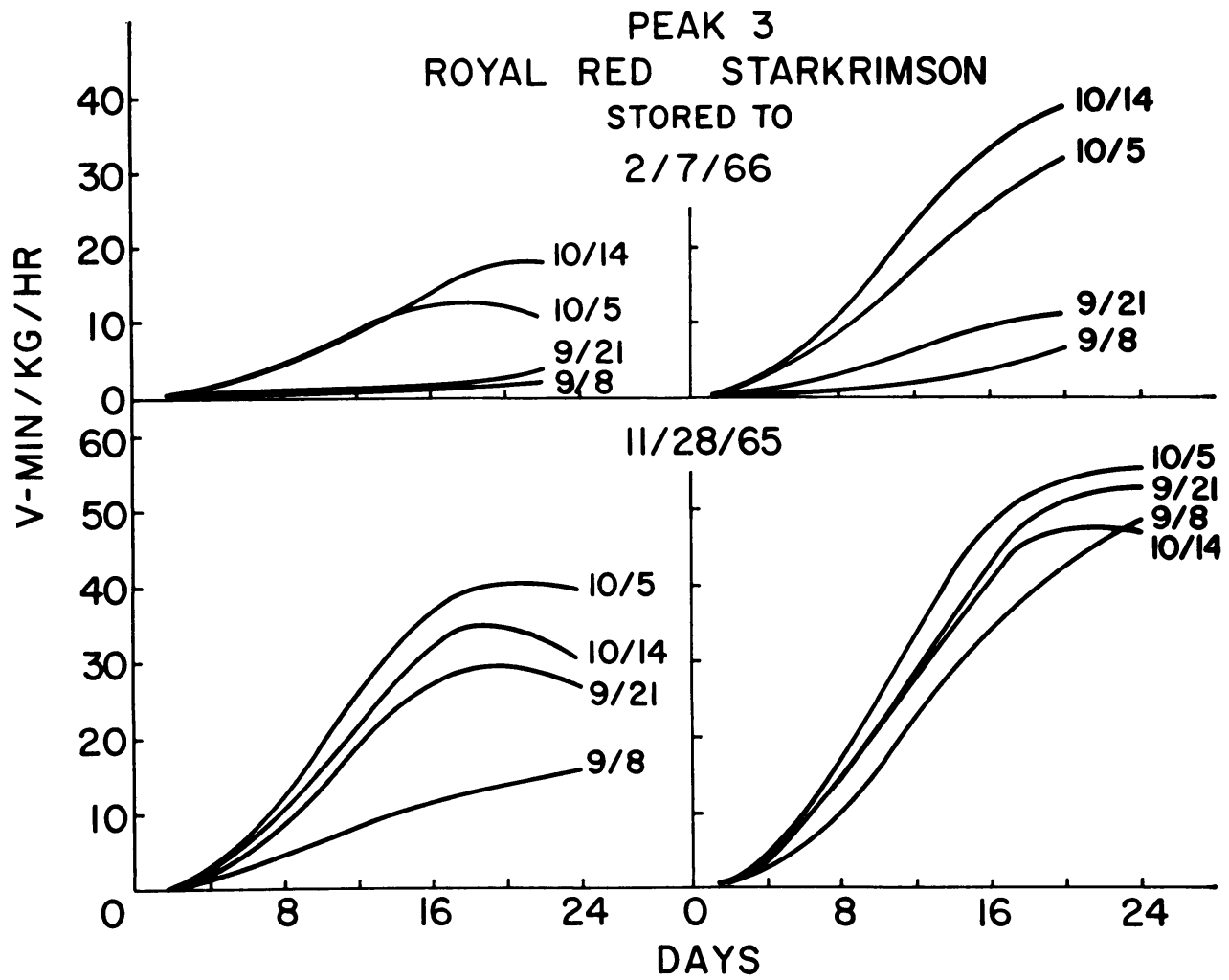

Fig. 10. Production curves for the volatile at Peak 3 as determined on the FFAP column for Royal Red Delicious and Starkrimson following storage at $32^{\circ} \mathrm{F}$ from the indicated harvest dates in 1965 until November 28, 1965 and February 7, 1966.

Starkrimson (figs. 1 and 10). However, rates of production of this volatile from both varieties after storage until February were lower than from freshly harvested samples regardless of the picking dates (figs. 1 and 10). The differences were greatest for the earliest pickings which were most immature. Grevers and Doesburg (1965) noted that the production of volatiles after storage decreased as the preceding storage time increased. They observed that the greatest amounts of volatiles were produced at the end of 2-months storage, and then decreased.

There were generally higher rates of production after storage until late November but lower rates after storage until February for peak $6,7 \mathrm{a}$ and $7 \mathrm{~b}$ volatiles. With the peak 11 volatile, however, rates of production after both storage periods were lower than from the freshly harvested samples (figs. 4 and 13). The lower volatile production after storage until February was also reported for samples from Sebastopol in 1964 (Brown et al., 1966). Except for the peak 3 volatile, the rates of production attained within the first 3 to 5 days were markedly higher from the samples which had been stored than from the freshly harvested samples (figs. 1 to 4,10 to 14 ).

Ruby and Melrose. Figures 15 and 16 show chromatograms typical of samples of volatiles from Ruby and Melrose as developed with the two columns. Chromatograms of Ruby (fig. 15) were similar to those of Delicious sports (fig. 


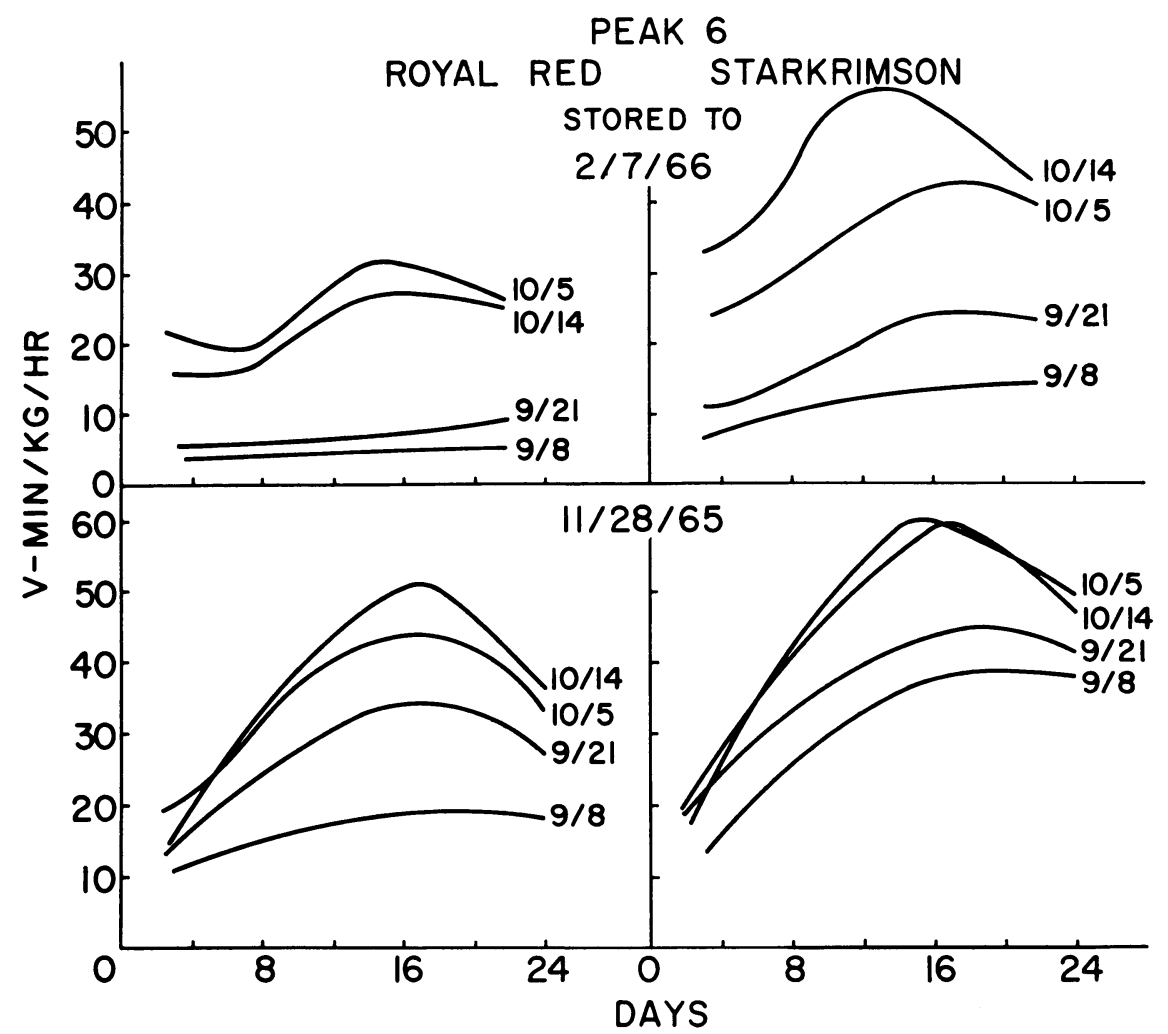

Fig. 11. Production curves for the volatile at Peak 6 as determined on the FFAP column for Royal Red Delicious and Starkrimson following storage at $32^{\circ} \mathrm{F}$ from the indicated harvest dates in 1965 until November 28, 1965 and February 7, 1966.

$5)$, but with some variation in relative amounts of some components. Volatiles at peaks $2,3,5$, and $7 \mathrm{~b}$ were more prominent from Ruby (fig. 15) than from Starkrimson (fig. 5), while those at peak 11 were less. Such differences might be related more to differences in relative maturity of the samples than to differences in the varieties themselves. Differences between varieties are better indicated by production curves for the volatiles.

Chromatograms of the volatiles from Melrose (fig. 16) were characterized by a strikingly low peak height for all components, compared to those of Starkrimson (fig. 5) and Ruby (fig. 15). Low production of volatiles by Melrose was characteristic of the variety regardless of fruit maturity. Vola- tiles at peaks 2,10 , and 12 either were not produced by Melrose or were evolved at levels so low as to be undetectable with the columns used.

Rates of $\mathrm{C}_{2} \mathrm{H}_{4}$ production by Ruby were higher than those from Starkrimson or Royal Red Delicious (figs. 8, 9, and 17), while rates of $\mathrm{CO}_{2}$ production by the three varieties were about the same. Ruby fruit picked on October 14 was relatively the least mature of the three harvests. There were no differences in maturity between the two later harvests in terms of soluble solids or firmness (table 9), although slightly earlier peaks in $\mathrm{CO}_{2}$ and $\mathrm{C}_{2} \mathrm{H}_{4}$ production for fruit picked on November 4 suggest that it was the more mature (fig. 17).

Differences in maturity were also 


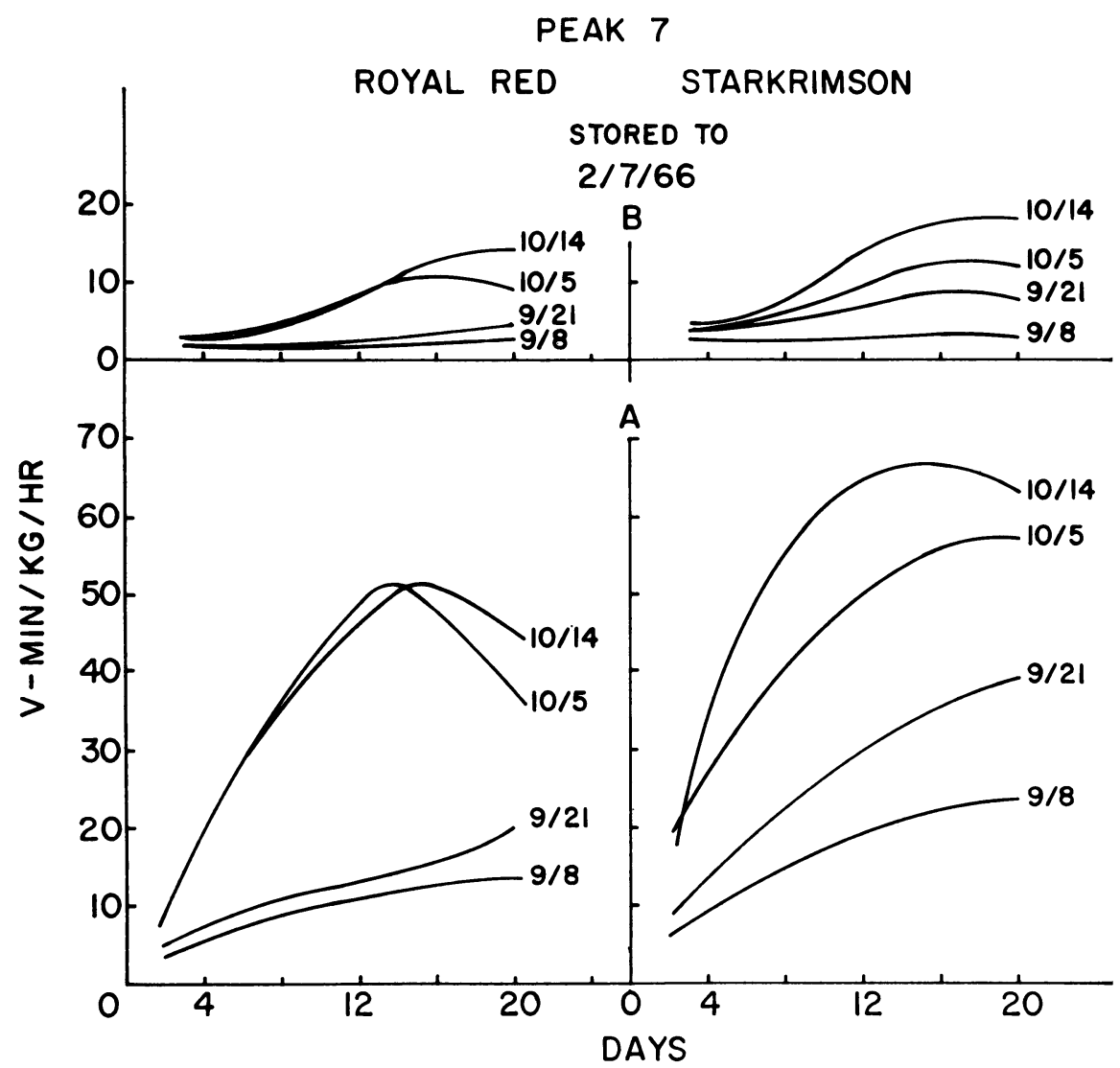

Fig. 12. Production curves for the volatiles at Peaks $7 \mathrm{~A}$ and $7 \mathrm{~B}$ as determined on the FFAP column for Royal Red Delicious and Starkrimson following storage at $32^{\circ} \mathrm{F}$ from the indicated harvest dates in 1965 until February 7, 1966. 


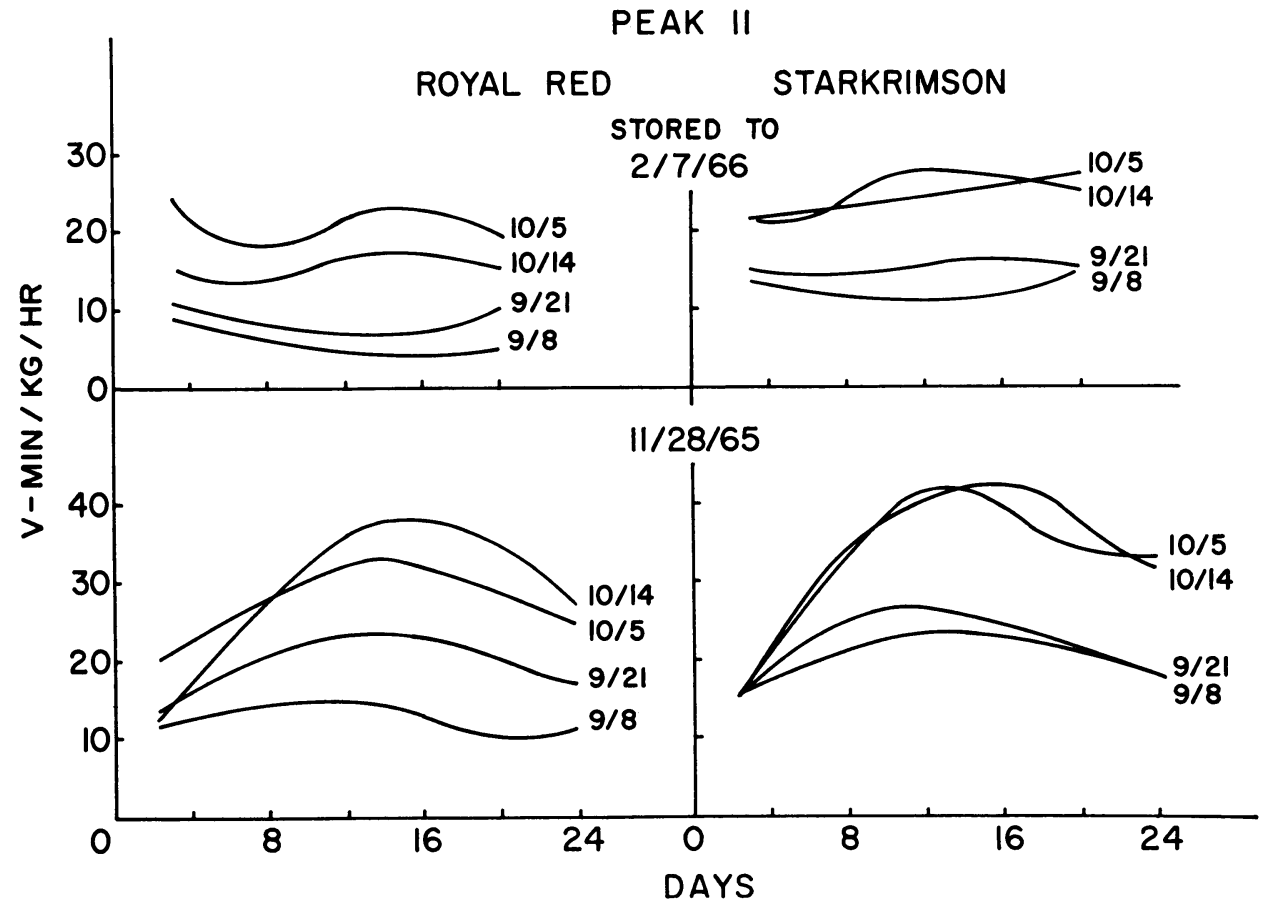

Fig. 13. Production curves for the volatile at Peak 11 as determined on the FFAP column for Royal Red Delicious and Starkrimson following storage at $32^{\circ} \mathrm{F}$ from the indicated harvest dates in 1965 until November 28, 1965 and February 7, 1966. 


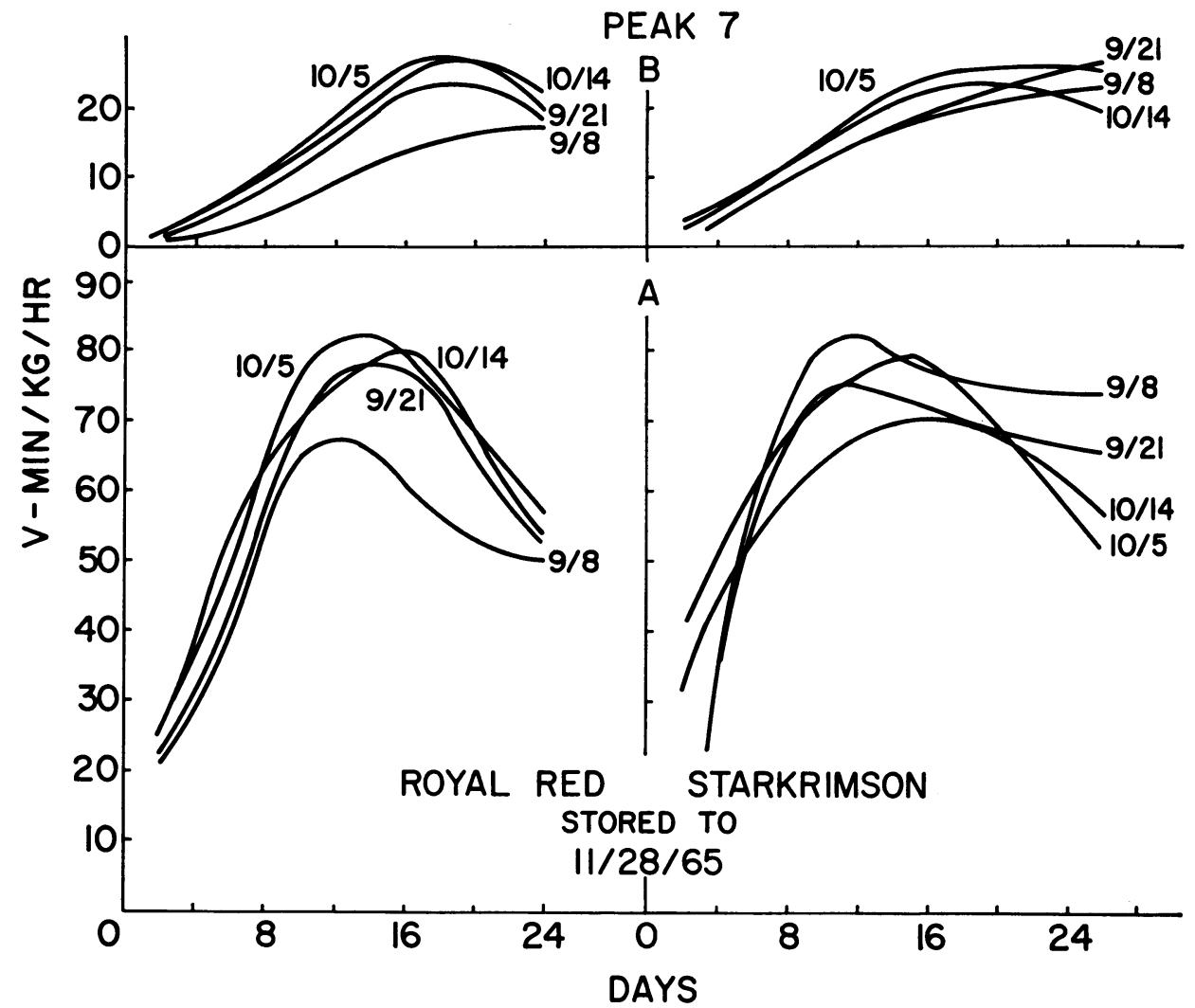

Fig. 14. Production curves for the volatiles at Peaks $7 \mathrm{~A}$ and $7 \mathrm{~B}$ as determined on the FFAP column for Royal Red Delicious and Starkrimson following storage at $32^{\circ} \mathrm{F}$ from the indicated harvest dates in 1965 until November 28, 1965. 


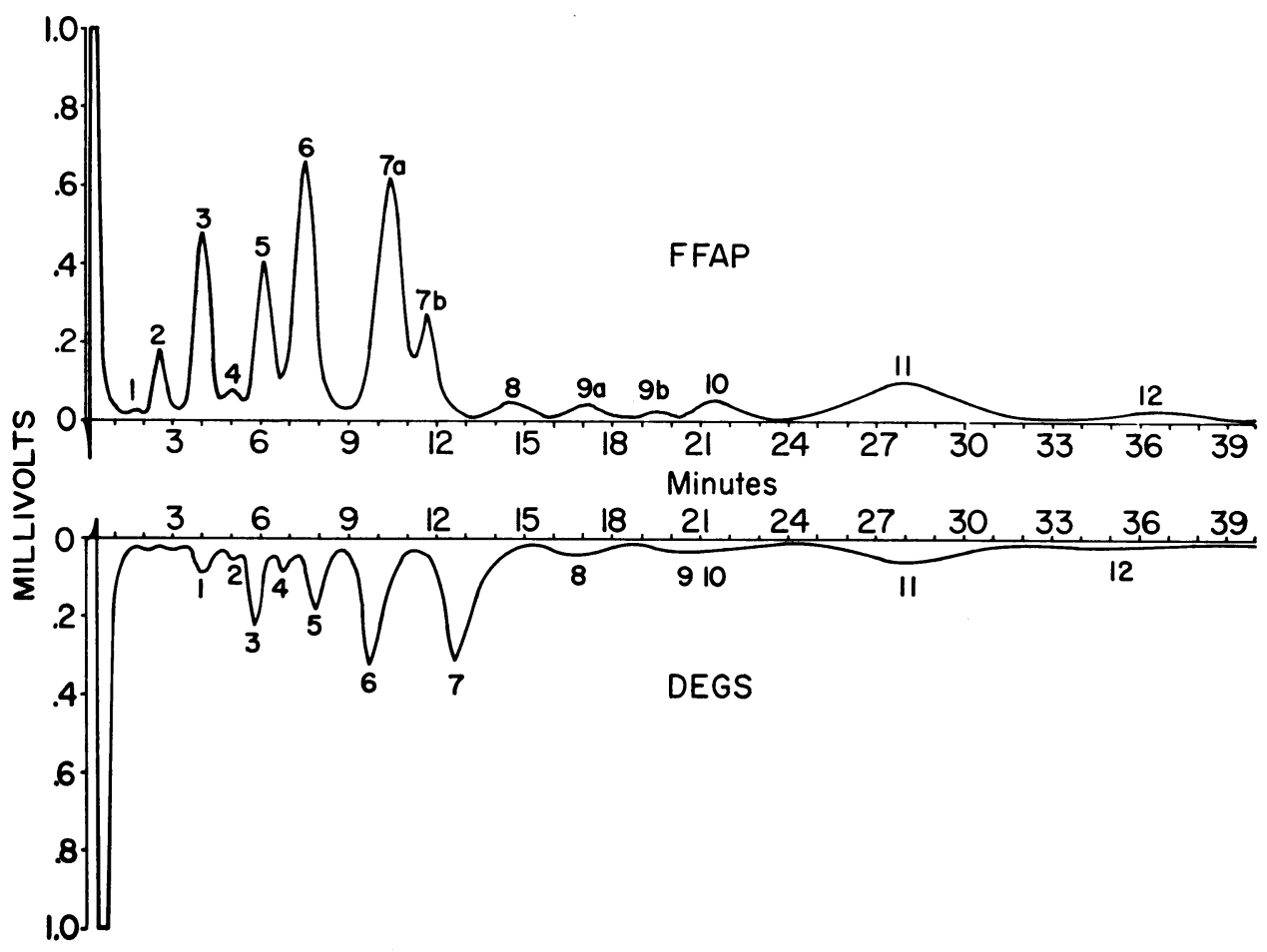

Fig. 15. Typical gas chromatograms of volatiles from mature Ruby apples, 2 days past the respiratory climacteric, as measured on two columns, one coated with diethylene glycol succinate (DEGS) and the other with FFAP, November 1965 (attenuation 8x) 


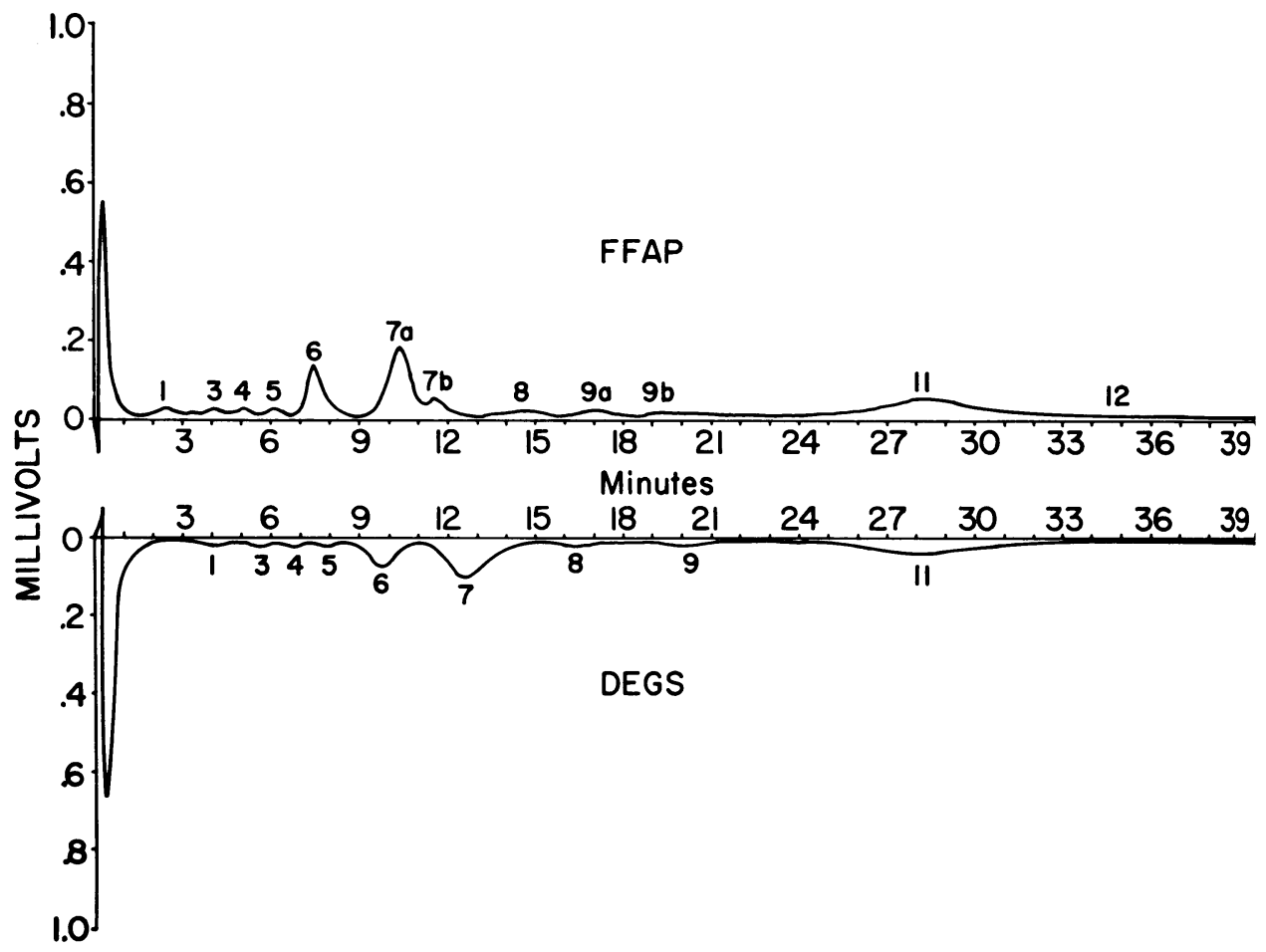

Fig. 16. Typical gas chromatograms of volatiles from mature Melrose apples, 3 days before the respiratory climacteric, as measured on two columns, one coated with diethylene glycol succinate (DEGS) and the other with FFAP, October 1965 (attenuation 8x).

indicated by successively earlier maximums of volatile production as harvests were later (figs. 18 and 19), although there was no consistent pattern among these volatiles from Ruby in terms of maximum rates of production reached with samples at different harvest dates. Production rates attained by the component of peak 3 were generally similar to those of Royal Red Delicious in 1965 but slightly lower than those of Starkrimson (figs. 1 and 18). Rates for the components of peaks 6 and 11 were generally lower than those of either Royal Red or Starkrimson in 1965 (figs. 2, 4 and 18). Rates of the volatile at peak $7 \mathrm{a}$ were lower, and those for peak $7 \mathrm{~b}$ equal to or slightly higher from Ruby than those from the Delicious sports (figs. 3 and 19).

Rates of production of these volatiles by Ruby after cold storage (tables 3 and 4) were lower than those from the fruit shortly after harvest. In the first 3 to 5 days after removing apples from storage, volatiles generally attained levels considerably higher than those initially produced by the freshly harvested apples.

Melrose samples. $\mathrm{C}_{2} \mathrm{H}_{4}$ production by Melrose (fig. 20) was extremely low, attaining rates only one-fifth to onefourth of those reached by Starkrimson or Royal Red Delicious, and approximately one-sixth those reached by Ruby (figs. 8, 9 and 17). Maximum rates of $\mathrm{CO}_{2}$ production by Melrose were also lower than those of the other varieties.

The Melrose apples picked on September 21 and on October 5 were similar, and definitely immature compared to those harvested October 14 and 28 (table 9 and fig. 20). Curves for volatiles at peaks $3,6,7 \mathrm{a}, 7 \mathrm{~b}$, and 11 also 
are paired according to different harvest dates, thus reflecting differences in maturity between the pairs (figs. 21 and 22$)$.

Although levels of volatiles from Melrase were only $20 \mathrm{v}$-min $/ \mathrm{kg} / \mathrm{hr}$ or less, production curves in figures 21 and 22 are generally similar to those of the other varieties insofar as differences in fruit maturity at different harvest dates are concerned. Immaturity of

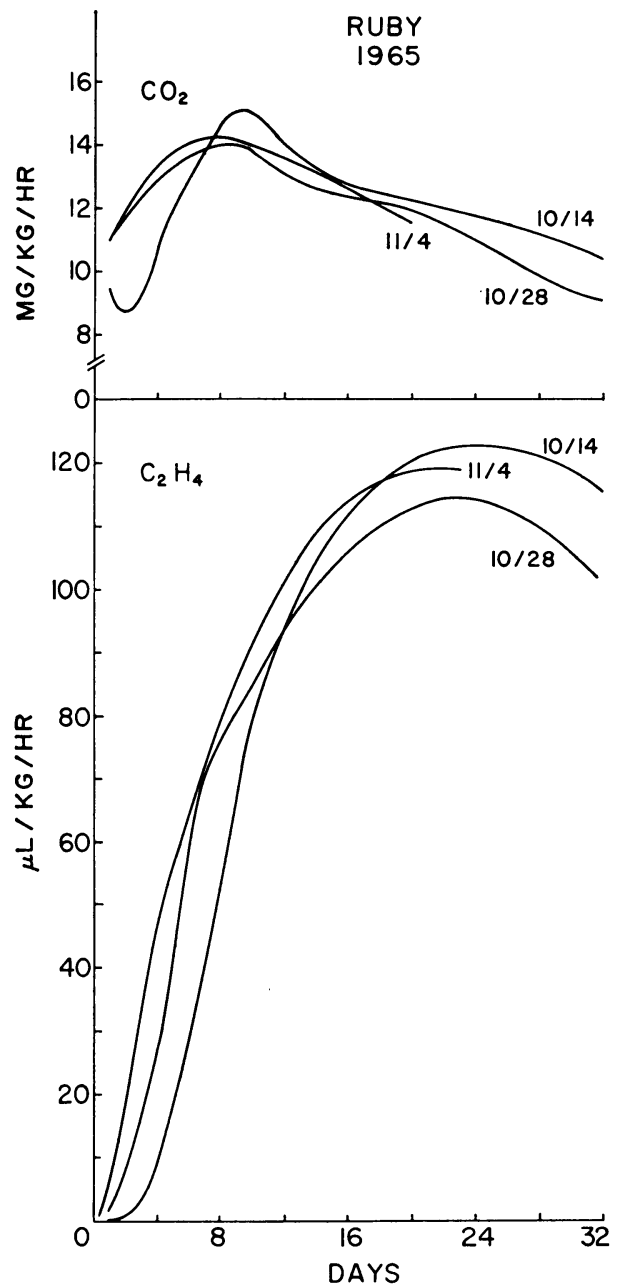

Fig. 17. Rates of $\mathrm{CO}_{2}$ and $\mathrm{C}_{2} \mathrm{H}_{4}$ production for Ruby in 1965 as determined at $68^{\circ} \mathrm{F}$ over a 32-day period beginning shortly after the harvest dates indicated.

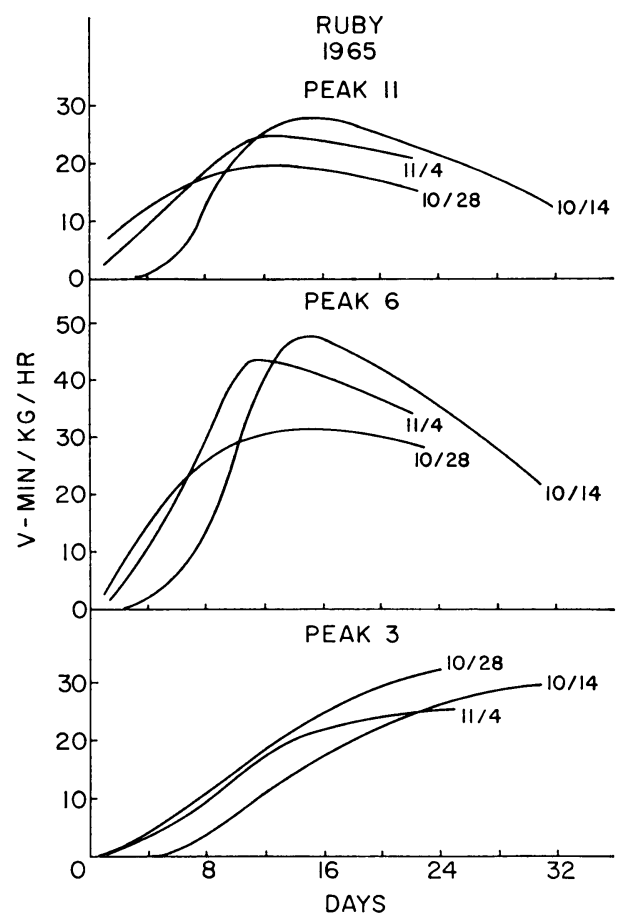

Fig. 18. Production curves for the volatiles at Peaks 3, 6 and 11 as determined on the FFAP column in 1965 for Ruby shortly after harvest dates indicated.

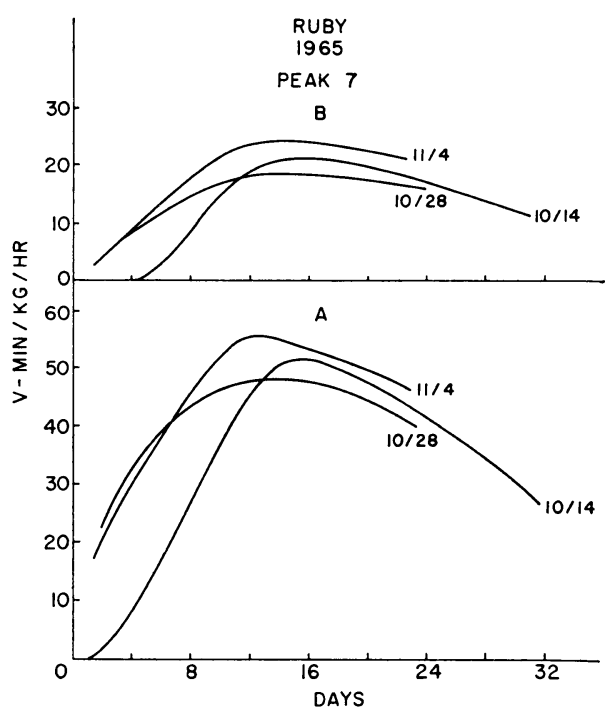

Fig. 19. Production curves for the volatiles at Peaks 7A and 7B as determined on the FFAP column in 1965 for Ruby shortly after harvest dates indicated. 
TABLE 9

AVERAGE FIRMNESS AND SOLUBLE SOLIDS VALUES FOR MELROSE AND

RUBY APPLES AT DIFFERENT DATES OF PICKING IN 1965

\begin{tabular}{r|c|c|c|c}
\hline & \multicolumn{2}{|c|}{ Melrose } & \multicolumn{2}{c}{ Ruby } \\
\cline { 2 - 5 } Harvest date & $\begin{array}{c}\text { Firm- } \\
\text { ness } \\
\text { (lb.) }\end{array}$ & $\begin{array}{c}\text { Soluble } \\
\text { solids } \\
\text { (per } \\
\text { cent) }\end{array}$ & $\begin{array}{c}\text { Firm- } \\
\text { ness } \\
\text { (lb.) }\end{array}$ & $\begin{array}{c}\text { Soluble } \\
\text { solids } \\
\text { (per } \\
\text { cent) }\end{array}$ \\
\hline $9 / 21 \ldots \ldots \ldots \ldots$ & 17.2 & 12.2 & $\ldots$. & $\ldots$ \\
$10 / 5 \ldots \ldots \ldots \ldots$ & 17.2 & 12.0 & $\ldots$. & $\ldots$ \\
$10 / 14 \ldots \ldots \ldots \ldots$ & 15.7 & 12.4 & 20.7 & 10.8 \\
$10,28 \ldots \ldots \ldots \ldots$ & 15.9 & 13.0 & 20.1 & 11.8 \\
$11 / 4 \ldots \ldots \ldots \ldots$ & $\ldots \ldots$ & $\ldots \ldots$ & 20.1 & 11.8 \\
\hline \hline
\end{tabular}

fruit at the two earlier harvest dates is shown by the low rates of volatile production, and by a delayed and slower rate of evolution as compared to fruit from later pickings. Curves for more mature fruit generally show rapid pro-

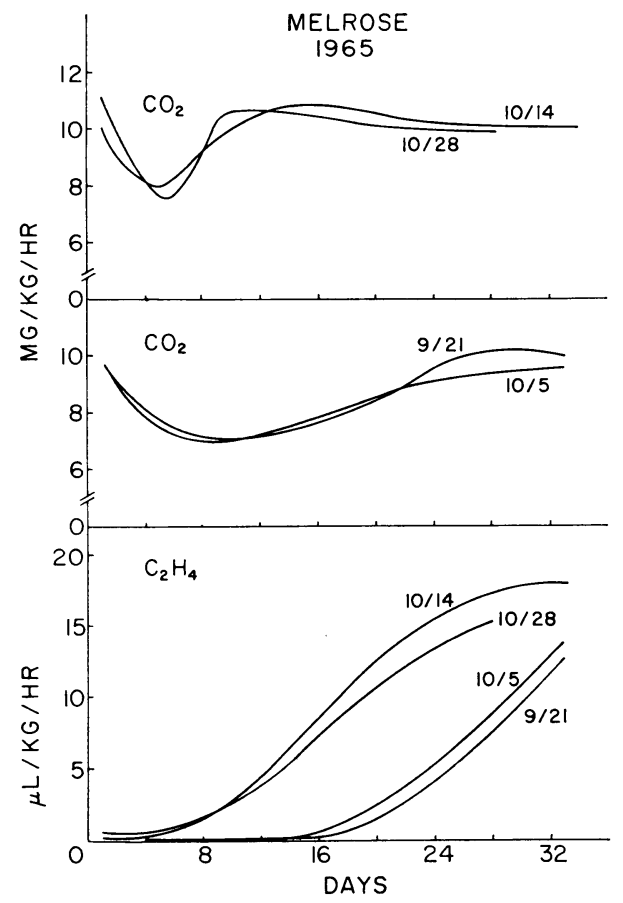

Fig. 20. Rates of $\mathrm{CO}_{2}$ and $\mathrm{C}_{2} \mathrm{H}_{4}$ production for Melrose in 1965 as determined at $68^{\circ} \mathrm{F}$ over a 32-day period beginning shortly after the harvest dates indicated.

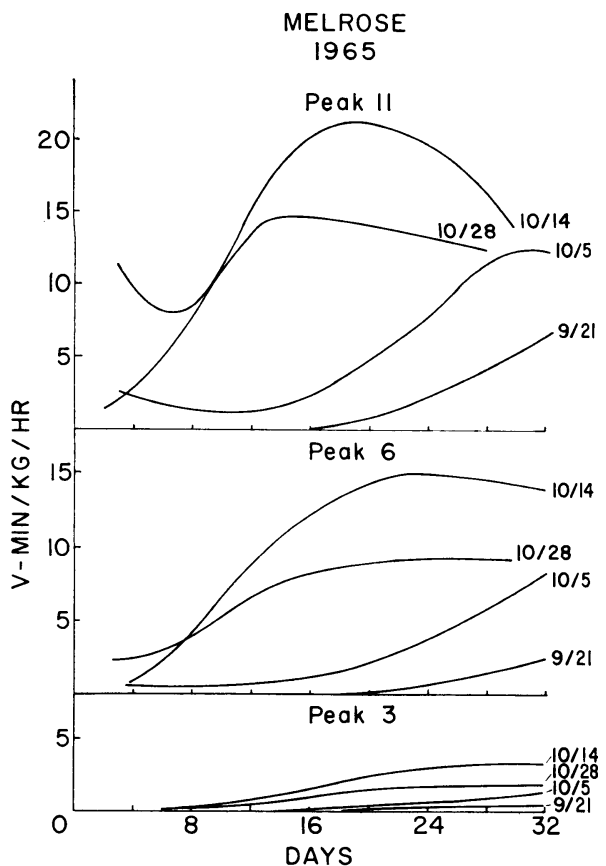

Fig. 21. Production curves for the volatiles at Peaks 3, 6 and 11 as determined on the FFAP column in 1965 for Melrose shortly after harvest dates indicated.

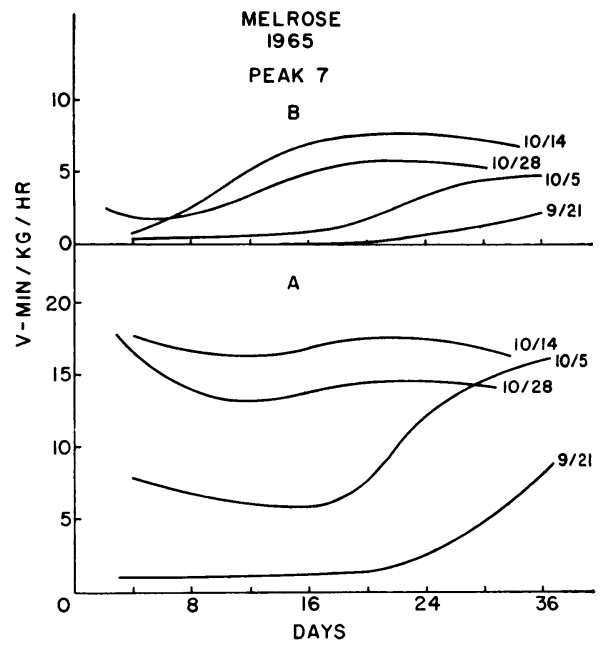

Fig. 22. Production curves for the volatiles at Peaks $7 \mathrm{~A}$ and $7 \mathrm{~B}$ as determined on the FFAP column in 1965 for Melrose shortly after har. vest dates indicated. 
duction of volatiles, reaching maximums in 10 to 20 days. The nearly uniform or slightly declining rate of production of the peak $7 \mathrm{a}$ volatile from the October 14 and 28 harvest of Melrose was, however, atypical for freshly harvested samples and more like that of some stored fruits.

Production rates of the volatiles from Melrose after storage at $32^{\circ} \mathrm{F}$ (tables 5 and 6) were generally lower than those of fruit tested shortly after harvest, except for the peak 7a volatile, which tended to be slightly higher after storage than before. In general, volatile production rates were higher in the first 3 to 5 days after apples were removed from storage than they were in the same time shortly after harvest. Even relatively immature apples from the first two pickings (which did not produce measurable amounts until 1 to 2 weeks after harvest) produced measurable amounts of the volatiles within 4 days after removal from storage.

It is surprising that production of volatiles by Melrose was so different from other varieties reported on here, as both Ruby and Melrose have some parentage in common and through it a relationship to Royal Red Delicious and Starkrimson. Ruby is a cross of Gallia Beauty $\times$ Starking Delicious, and Melrose is a cross of Jonathan $\times$ Delicious. With Delicious as a parent, the chromatographic pattern of the Melrose volatiles might be expected to resemble those of Starkrimson and Royal Red Delicious more closely, particularly because the pattern of Ruby volatiles, with Starking as a parent, is similar to patterns of Delicious varieties.

\section{SUMMARY AND CONCLUSIONS}

Differences between Starkrimson and Royal Red Delicious in time of maturation and production of volatiles were not consistent over two seasons of observation for freshly harvested or stored fruits. Thus, Royal Red apparently matured earlier than Starkrimson in 1964, but not in 1965 . In both years, however, Starkrimson consistently had slightly higher rates of $\mathrm{C}_{2} \mathrm{H}_{4}$ production than did Royal Red. Starkrimson also produced higher levels of the volatile at peak 3 in both years than did Royal Red, and with both freshly harvested and stored apples. In 1964, the two varieties did not differ consistently with respect to the volatiles at peak 6, but in 1965 Starkrimson produced it at higher rates than did Royal Red right after harvest and after storage as well. As measured on the DEGS column in 1964 , the two varieties did not seem to differ with respect to the components of peak 7. In 1965 (with the FFAP column) there were no consistent differences between the two va- rieties in production of volatiles at peaks $7 \mathrm{a}$ and $7 \mathrm{~b}$, except for apples after 6 months of storage-Starkrimson then produced these volatiles at slightly higher rates than did Royal Red. There were no consistent differences in the production of the volatile at peak 11 in 1964, but in 1965 Starkrimson produced it at somewhat higher rates than did Royal Red, both shortly after harvest and after storage.

The chromatograms of Ruby were generally like those of Starkrimson and Royal Red Delicious. Production curves for the peak 3 volatile were quantitatively more like those of Royal Red than Starkrimson, which had the highest rates of production for this volatile. The production rates of volatiles at peaks 6 and 11 were generally lower from Ruby than from the Delicious varieties. The volatile at peak $7 \mathrm{a}$ was also lower from Ruby, while that at peak $7 \mathrm{~b}$ was about the same as from Starkrimson and Royal Red. A higher rate of $\mathrm{C}_{2} \mathrm{H}_{4}$ production was the most 
striking difference between Ruby and Starkrimson and Royal Red.

The rates of production of $\mathrm{CO}_{2}, \mathrm{C}_{2} \mathrm{H}_{4}$ and other volatiles from Melrose were all strikingly lower than those from Ruby or the Delicious varieties. No volatile was detected from Melrose at peak 10, and others usually associated with senescent changes in the fruit (particularly those at peaks 2 and 12) were detected only at low levels and only from overripe fruit.

The Delicious parentage of Ruby is suggested by the general similarity between the production patterns of its volatiles and those of Starkrimson and Royal Red. However, the volatile patterns of Melrose seem quite unrelated to its Delicious parentage.

Results with the four varieties suggest the following generalizations:

The more mature the apples, the less time was required following harvest to reach the respiratory climacteric and maximum production rates of all volatiles.

The more mature the fruit, the earlier a measurable quantity of a volatile was detected following harvest. Appreciable quantities of the volatiles often were not detected for 1 or 2 weeks immediately after harvest, depending upon the maturity of the apples, whereas after storage relatively high initial rates of production of most of them occurred within 3 to 5 days, except from very immature apples.

Maximum production rates of a volatile after the apples were stored for approximately 6 months were much lower than those right after harvest, particularly with apples which were immature. After 3 months of storage or less production rates of volatiles were nearly the same or higher than those from freshly harvested apples, except for the component of peak 11, which was lower from Starkrimson and Royal Red Delicious after both periods of storage than it was right after harvest.

Comparison of relative retention times for known alcohols and esters with those for the peaks of the apple volatiles provided some evidence as to the identity of the volatiles. On this basis, the components of the five peaks primarily referred to in this study possibly were: peak 3 , propyl acetate; peak 6 , butyl acetate; peak 7a, isopentyl acetate; peak $7 \mathrm{~b}$, butanol; and peak 11, hexyl acetate. 


\section{LITERATURE CITED}

Aнmed, E. M., and L. E. ScotT

1963. Gas-liquid chromotography studies with strawberries. Proc. Amer. Soc. Hort. Sci. 82: 299-310.

ANDERSON, R. E.

1965. Volatiles and atmosphere purification in storage. A review of literature on harvesting, handling, storage and transportation of apples. U.S.D.A. Agr. Res. Serv. ARS 51_4: 102-11.

Brown, Dillon S., J. R. Buchanan, and J. R. Hicks

1966. Volatiles from apple fruits as related to variety, maturity, and ripeness. Proc. Amer. Soc. Hort. Sci. 88:98-104.

ClaYPOOL, L. L., and R. M. KEEFER

1942. A colorimetric method for $\mathrm{CO}_{2}$ determination in respiration studies. Proc. Amer. Soc. Hort. Sci. $40: 177-86$.

Flath, R. A.

1967. New techniques in fruit volatiles research. Agr. Sci. Rev. 5:27-32.

Flath, R. A., D. R. Black, D. G. Guadagni, W. H. McFadden, and T. H. Schultz

1967. Identification and organoleptic evoluation of compounds in Delicious apple essence. J. Agr. and Food Chem. 15:29-35.

Grevers, G., and J. J. Doesburg

1965. Volatiles of apples during storage and ripening. J. Food Sci. 30:412-15.

HUELIN, F. E.

1952. Volatile products of apples III. Identification of aldehydes and ketones. Australian J. Sci. Res., Ser. B. $5: 328-34$.

Hulme, A. C.

1958. Some aspects of the biochemistry of apple and pear fruits. Advances in Food Res. 8:297-413.

LIM, L., and R. J. RomanI

1964. Volatiles and the harvest maturity of peaches and nectarines. J. Food Sci. 29:246-53.

MacGregor, D. R., H. Sugisawa, and J. S. Mathews

1964. Apple juice volatiles. J. Food Sci. 29:448-55.

Maxie, E. C., I. L. Eakes, N. F. Sommer, H. L. RaE, and S. El-Batal

1965. Effect of gamma radiation on rate of ethylene and carbon dioxide evolution by lemon fruit. Plant Physiol. 40:407-09.

Pentzer, W. T., and P. H. Heinze

1954. Postharvest physiology of fruits and vegetables. Ann. Rev. Plant Physiol. 5:205-24.

SMOcK, R. M., and A. N. NeUBERT

1950. Apples and apple products. N.Y.: Interscience Publ., Inc.

Somogyi, L. P., N. F. Childers, and S. S. Chang

1964. Volatile constituents of apple fruits as influenced by fertilizer treatments. Proc. Amer. Soc. Hort. Sci. 84:51-58.

StackenbroK, K. H.

1961. Nachweis sortenspezifischer apfelaromen. Der Erwerbsobstbau 3:147-48.

Thompson, A. R.

1951. Volatile products of apples. I. Identification of acids and alcohols. Australian J. Sci. Res., Ser. B. 4:283-92.

Thompson, A. R., and F. E. HuElin

1951. Volatile products of apples. II. Production of volatile esters by Granny Smith apples.

ULRICH, $R$. Australian J. Sci. Res., Ser. B. 4:544-53.

1958. Postharvest physiology of fruits. Ann. Rev. Plant Physiol. 9:385-416.

In order that the information in our publications may be more intelligible it is sometimes necessary to use trade names of products or equipment rather than complicated descriptive or chemical identifications. In so doing it is unavoidable in some cases that similar products which are on the market under other trade names may not be cited. No endorsement of named products is intended nor is criticism implied of similar products which are not mentioned. 

The journal HILGARDIA is published at irregular intervals, in volumes of about 650 to 700 pages. The number of issues per volume varies.

Single copies of any issue may be obtained free, as long as the supply lasts; please request by volume and issue number from:

$$
\begin{aligned}
& \text { Agricultural Publications } \\
& \text { University Hall } \\
& \text { University of California } \\
& \text { Berkeley, California } \mathbf{9 4 7 2 0}
\end{aligned}
$$

The limit to nonresidents of California is 10 separate titles. The limit to California residents is 20 separate titles.

The journal will be sent regularly to libraries, schools, or institutions in one of the following ways:

1. In exchange for similar published material on research.

2. As a gift to qualified repository libraries only.

3. On a subscription basis- $\$ 7.50$ a year paid in advance. All subscriptions will be started with the first number issued during a calendar year. Subscribers starting during any given year will be sent back numbers to the first of that year and will be billed for the ensuing year the following January. Make checks or money orders pay. able to The Regents of The University of California; send payment with order to Agricultural Publications at above address. 